\title{
An Attitude Scale for the Assessment of Morale in a Psychiatric Hospital
}

William Gregory Klett

Loyola University Chicago

Follow this and additional works at: https://ecommons.luc.edu/luc_diss

Part of the Psychology Commons

\section{Recommended Citation}

Klett, William Gregory, "An Attitude Scale for the Assessment of Morale in a Psychiatric Hospital" (1963). Dissertations. 659.

https://ecommons.luc.edu/luc_diss/659

This Dissertation is brought to you for free and open access by the Theses and Dissertations at Loyola eCommons. It has been accepted for inclusion in Dissertations by an authorized administrator of Loyola eCommons. For more information, please contact ecommons@luc.edu. (c) $($ ) $\Theta \Theta$

This work is licensed under a Creative Commons Attribution-Noncommercial-No Derivative Works 3.0 License. Copyright @ 1963 William Gregory Klett 


\title{
AN ATTTHODE SCALE FOR THE ASSESTAET OF MORALE \\ II A FGYCHIATRIC FOSPIAL
}

\author{
by \\ Willem Gregory nott
}

A D1seartation Subuitted to the Faculty of the Graduate Sehool of Loyola Undvoraity in Partiel Furfiliment of the Requiremente for the Degree of Dooton of Phtlosophy

Jamaxy

1963 


\section{LITE}

W1111am Gregory Klett was born on December 9, 1929, in St. Paul, Minnosota. In 1947 he was gradusted from Crotin High Sohool in st. Pawl, and In 1951 he reoefred the degree of Bechelor of Arti from the College of St. Thomas, also in St. Paul.

From 1952 to 1954 the author was a menber of the armed forces, serving as a persomel managoment opectallet for the 9829th Technioal Serviee Unit, Onited States Armg Corps of Engineers. Following his honorable separation Pron the Army he was omployed as a morohandiser and atditor by Montgonory Ward and Company. Ho began his graduate studies at Loyole Univarafty in February, 1955, and recelved the degree of Hastar of Arts in Fobruary, 2959.

From 1956 to 1960 the suthor was a psychologlat on the stafe of the Cathollo Charitles Cutdanoe Center, Chloago, Illinols. In September, 1960, ho realgned from Cathollo Charitios and beame a traines in the Veterans Admintstration tralning Irogram for olinicel psychology. Since ontering the program he has recelved training at Hines and Downey Veterans Adrainistaration hos pitals. 


\section{ACKNOWLEDGANIS}

The writer is Indebted to Prank J. Kobler, Ph.D., Profeasor of Payohology and Direotor of Clinteal Training at Lopole Univereity, unier whose direotion this study was ocmpleted, for h1s continued interest and contruetive orltiolomo. Oraterul aoknowledgment is alwo wsde to Koith $\mathrm{K}$. Hoover, Fh.D., Coordinator of the Motivation Unit at Downey V. A. Hospital, and to Fred $\mathrm{h}$. Spaner, Ph.D., Chief of the Paychology Serviee there, for thetr permisation and encouragement to conduct the rosearoh doscribed in this diseertation, Thanks axe due to Donald Campbell, Ph.D., of Northweatern Univerolty for the enoouragenent and ocumel he roniered during the formative stages of this projeot. The advioe and analotanoe of H, J. A. RImold1, H,D., Ph, D., and John Haley, H.A., In the vealing of the date vere inverely appreolated.

The writor also wishas to expreas his approelation to Dra. Saul Kasman, Coorge Kats, Robert Barrell, and Kolth Hoover, to Mia Dowis Fushington, and to Messrs. Melvin Sohwarts, Miohael Partip110, and Thomas Tutko for the aseletanos thoy rendered in ovaluating and editing tho Intilal pool of otatemente from whioh the Instrument wed in this research was derived. The helphul muggestion of Leonard Borman, Chlef of the Anthropology Service at Downey V. A. Hoapital, and of Farren Thisean, Fh, D., Director of the Peyohology Researoh Iaboratory thero wore 11kewlse approolated.

Pinslly, the witer wishes to expreas his apprealation to Mra. Marlene Mett and Mre. Jan Mandahl and Mro. Sandy Burrott for their asalotanoe in the proparation of this manusorlpt. 
TABL of COMrens

Chapter

Page

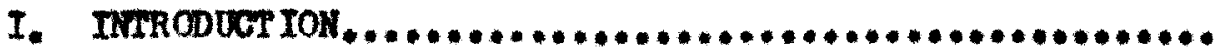

Historical beokground-Recent developments in scoial poyohiatary-statement of problem

II. REVIEW CF RELATED LITERATURE.....................

Morale publieation-Darintion of morale-

Moacuredent of morale-attitude studies.

IIT. DESION OP THE RESEARCH IMSTRDABMIS.................

Developuent and convtruotion of the attitude coalem Proeedires for collection of statemente-Prelininary form of seale-Seleotion of statements for Anal formmSoaling of statomente.

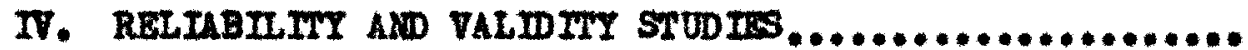

Rationale-Rollability experimonts and hypothoses-

Validity experiment--Desoription of treatment eotting.

v. ARALYSIS OP RESULIS ..............................

Reaulta of rellablifty experinents-Internal oonalstenoy of soale-stability of cooresm-Presentation of dataRocults of vildity experiment-Preventation of datamDisousetion of resulte.

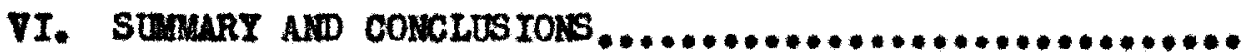




\section{LIST OF TABLAS}

Table

1. STANDAPD DEVIATIOAS, SCALE VALUAS, AND NCRHAL DEV IATE HEIOHE POR STATEMBNS ON THE PATIENS OPINION FOLL.

2. CHANOES IN MEAN SCORE ON THE PATIEMS OPINION POLL as A RESULT of FOUR WTERS EXPOSURE TO THE EXPAR TMEMTAL TREATUEAYI SEIT IMG.................................. 


\section{LIST OF FIGURES}

Plgare

Pago

1. DTSTR IBUTION OF SOALE VALUES FOR THE 28 STATEAENS OF TUE

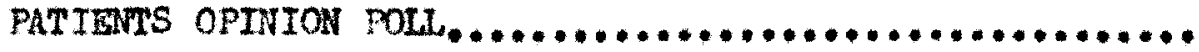

2. RELATIONSHIP BETWEEN IMTBCRAL AMT NORMAL DEVIATE WEIGHS

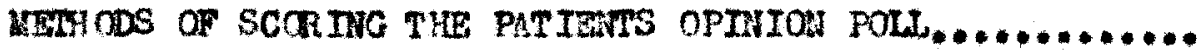

52

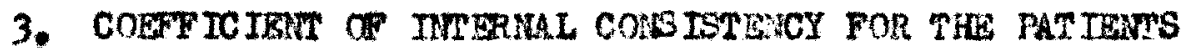
OPTNTON POLL.........................................

4. COHF ICIEN OF STABILITY FOR THE PATIEMS OPINION POLL... 
Interest in the social dimenalon of the montal hoapltal has been inorealing steadily sinoe Forld War II. The reporte of payohiatriste who had witnesed the strong Influenoe of soclal forces upon the recovery of armed forced personnel hospltalized for peychiatrio condition (Bridges, 1943 , Michnels, 1947, Jones, 1953) otimulated oonsiderable enthuslasw in this area. The finding of aocial solentiets interosted in the organtzation and soofal atruoture of montal hospitals and in their effect upon the bahavior and olinteal oouree of the patient generated further intereat. The studies of Stanton and Sohwarts $(1949,1950,1954)$, Rapoport (1956, 1957), Caud111 (1958), and Parker (1958, 1959), to name but a few, dooumented the interrelatodinas of actions in the montel hospltal and 11lustrated how adniniatrative action and interpersonal relations offeot the progresa of patiente. These rindinge and parallel dovelopeenta in the rleld of ego payohology (Hartwan, 1951) and 80010-oultwal thoory (G11lon, 1955; Merton, 1957) underlie the dramatio ohanges whioh are coourring in wental hospltals.

A generel trend away from ountodial managowent and toward humantet1e petiont oare is ovident in the ourrent 21terature dealing with aental howpltale. Orwator ireedom of movenent in being given to patients (Bell, 1955; Bloom, 1956). Now ohannels or communication are being oponed (De Ronis \& Campbell, 1958). Reaponaibility for the rehabliltation of patiente is being glvan to non-profeselonal hospltal workors (Br1g85, 1957, Greenblatt, 1955). 
The une of sedatives, restraints, and seclumion rooms has been drastioally ourtalled (Ariggs, 1958; Wilner, 1957).

In addition to the above ohanges, there have been a fon complote soorgantzations of large federal and state hoopitale (Buak Lawton, 1961; Bower Garala-Bunuel, 1962, Cole, 1962). All of these changes have Involved deoentrallsation in an effort to faollitate the eatablishnent and calntenanoe of interpersonal reletion in the hospital as well as to make way for aloser ties with the conmunities from whioh patiente oome and to whioh it is hoped they oan roturn. It is notewerthy that the roorganisation at clarinia, Iowa,

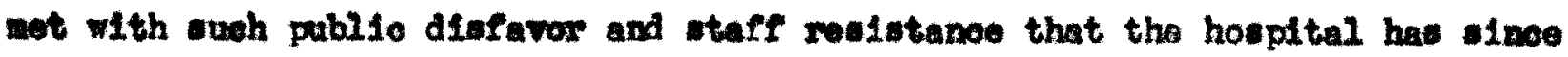
returned to its former mode of operation. The plan at Ptrblo, colorado, is now encountering scm pablic opponition (Anonyour, 1962; Oaborne, 1962), but hospital persomel and the goverwor of the etate are supporting the changen. Conourrent with the reont developmonts olted above have been a maber of roocamendation for revisions in the training of payohtatrio residants and in the pyohotherapeutio sodel which galdes wost wental hoapitals. Jones (1962) has eritlolsed the traditional training peograme for peyohtatrio rentdente, Indlating that thoy aro geared wore to the moda of private prootioe than of mental houpltale. He ween the poychiatrie ward as a soolal organization or oultwe which can be nodifled by soolo-peychologieal processes to the thoxapeutio edvantreg of patients and waxd personnel allke. Senultivity to the ooclal dimontion, which oan bo gained by the resident trained in the exanination of roles and role relationahipe on the waxd, lo rogarded Jonga

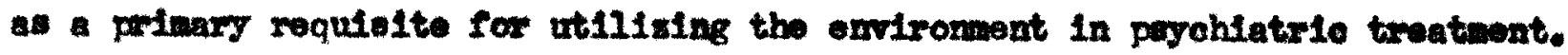


Vaughn (1962) has recommended a mofound soctal reorlentation in mental hospltals, he urges an acoeptence of the scolotherapeutlo model wherein all of a pationt contacts are onneidered potentialiy therapeutio and oproses what he ealls the current peychotherapeutio model. The latter model is characterized by a high regard for intenaive Individual paychotherapy and a view of personnel other than therapiats as poripheral and anolilary.

In general, the foregoing material illustrates the ourrent omphasis which is being pleced on what might be called scalo-peyohologtoal proossses. It is Implioftiy assumed a large number of contemporary soctal selentists that human behavior, espeelaliy pathological behavior, 18, for the nost part, a funotion of the social altuation in which it occurv. The influave of Harry Stack Sullivan's thinking (1931a) 1931b) is apparent. Disordered psyoholopleal funotioning is now wore than ever viewed as a dioturbanoe in intorpersonal relations. The "environentalist" carrles greater weight today, and he sees the manipulation of social sottings and groupe as the most effoetive kind of paychotherapg. A minority of Individuals, notably Herzberg and Hemlin (1961) and 肾ing (1962), maintein that mental 111 ness and empironment are logloally distinot and that each may vary independently of the other.

A notable development in the fleld of social payohiatry is the "thorapeutio community". This treatment 1reology is based on the assumption that personallty disorders are, for the most rart, caused by adverse environwental eipoumstanoes whloh prevent of interrupt normal personality development. Honee, the treatment and rehabilitation rocess oons1sts in exposing ouoh individuals to perwiosive and unioratanding soolal allien in whioh reality 
testing 1s emphasized. The onvalitarian-democratio aspect of the community facllitates self-awareness, self-control, and soclal recovary by fostering signifleant rolationships with others, by abandoning priviledged oommunication, and by eaphasizing communal oonfrontation (Rapoport, 1960). Community mothods of treatment heve been used with disturbed children and adolescents (Alchhorn, 1935; Bettelheim, 1950, Redl wineman, 1952), with nourot10 ex-prisoners of war (Bridgea, 1943), w1th peychopathe (Taylor, 1949), with adult personsity disorder of the anti-Boclal type (Jones, 1953, 1957), and with varlous types of psychiatrie eases (Jona \& Nathewa, 1956). The reaults of this approach have baen generally favorable, but reports deal mostly with the ahanges and progress being ade within individual treatment setting (w11mex, 1956, 1957; 1958, Briggs, 1958). Definitive finding are meagre, and systematic mean of following patients exposed to this kind of treatment have yot to be developed. Poxhaps, the most signifloant finding reported is that if treatment lasta 2es. than six wonths, then longth of otay is immaterial to adjuatment a year after disoharge, Rapoport (1960) reported in a followmp atudy of patiente treated at the Social Rohablitation Unit of Belinont Hoopital in England that fiftytwo percent of the peonle who were in treatment for almost seven wonths or longer are inproved year later, whlle only about one-third of all others were rated similariy.

Th1s study is coneerned wh the development and etandardization of a wethodology for examining one aspect of the soctal dimenaion of the mental hospltal. Spoolfloally, It deals with the construction of an attitude doale for wasuring and comparing the att1tures of paychlatrio pationte toward the partloular hospltal warde to which they are assigned. A flret resoaroh ain 
was to determine whother or not patiente differ in favorablenese of regard for their wards and, if so, what the pertinent areas of agroement and dieagrement are. A second alw was to develop a statistically reliable and valld Instrument whioh would be capable of ellolting olear differences of attitude toward the ward. In keoping with the latter aim, a thind goal was to dotermino Whother a 1gnifleant change in attitude, as moasured by the seale, coours as a result of expoeure to a therapeut10 comaunfty type of hospitel treatment in an experinontal hospltal ward.

The above researoh aims led to the formulation of the following hypothoses with which the present study is primarily oonoerned:

1. If the research 1nstrument is a rellable attitude weale, there will be a high comrelation between seores obtalned by the wase individual on two halves of the solle. Speolfleally, if the sttitude roalo oonalete of otatewonts which are interdepondent and howogonoows, a high coofflolent of internal oonelatenoy will be obtalned when the socres of respondente on the owen mubered statements of the seale are correlated with their soores on the add mubered statamente. Inpllelt in this proposition is the corollary that ocvaxiation among responses is assumed to be rolated to the variation of an underiging variable (Groen, 1954).

2. If the researoh instrument is a rellable attitude soale, there will be high oorrelation between scores obtalned by the same individual on two werarate cocalions, the poriod of time betwoen adulnistrations of the seale beling approximately two weoks. Speolfioally, if soores obtalned on the coale are atable, a high coefflelent of stablilty will be obtalned when the woores of reepondents on two separate administration of the veale are oorrelated. 
It is assuned in this proposition that no ovent of any real consequenoe will ocour In the intor $1 m$ between adinistrations so as to alter the attitudes of the respondente.

3. If the researoh instrument is a valid moaure of pationte' attitudes towsird their wards, then the mean score of a group of patients who have been exposed to a therapeutio comaunfty type of ward situation should be algnifioantly higher than the mean scowe of the aame group before exposure to this form of treatwent. It 18 as sumed in the above hypothesis that the experienoen which these patiente undergo in the experimental situation will be favorable and will faolittate changes in attitude in that direotion. Implatt in thia proponition is the ocrollary that validity refora to the extent to whioh the -ealo asseases the varlable it was designod to meanuro.

It was thought that this projeet would be of vilue in eeveral respects. It should reveal some quantitative data regarding aspeats of the ward situation which patients consider important, thereby ocmplenenting exlotent data obtained by direot questioning and partiolrant observation. Also, the ease and sped with which auch soale oould be administered should wake it possible to study and compare large groups of patiente. Further, the scale should provide social scientists, research personnel of paychiatrio hospltals, or hospltal administrators with oomenient means of determining the offeota of changes in treatmont prooedures, in hospital pollelea, in pereonmel, oto., upon the morale of patiente. For the auspielous or quiet patient who foels reluotant to speak openly, for example, during a patient counoll meeting, this soale would serve as a moans of comunleation, "a gxipe sheot," betweon hin and hospitel personnel. It could be used as ay of Identifying areas of 
conflict on a givon ward and, possibly, of prodloting suoh phonowena as treatment outoome, elopement, and longth of hoepdtellization required. 
REVIEW OF THE RELATED LITERATURE

4 review of the poychological 11terature rovealed number of pubilcations which are relevant to the present study. Sowe of thew deal explleltiy wth the attitudes of peychiatrie inpatients toward different features of the hospltal setting. while others are conoerned with the relationship of hospltal or ward norale to therapeutio outecue. They differ from the present otudy in terms of either purpose, population studied, mothod, or research design. There are a number of additional publicationa in the literatixe which relate to the prevent etudy in a more general ways they are concernod with the notions of att1tude and morale or with the moneuresent of these rhonomena. For the purpose of olarity, the related literature will be prosented and reviewed under two general headinge, one dealing with arrale and the other with attitude.

\section{Howala}

The importanos of ward or hospital morale has been atteoted to by several writers (KIonos, 1951; M1ehaels, 1947; Todd \&1ttkower, 1948). Al1 three of their reports are aneodotal acoounts of personsl expariences in vaxiout treatwent settings. They describe and augneot ways of improving norale, but they fall to offor any definitions of the term and they report no quantitative reaults.

Stanton and Sohwarta (1954) devoto an entire ohapter to Moralo and 1ta Breakdomn" in their etudy of the Eental hospital. They I1hewise wake no atteant 


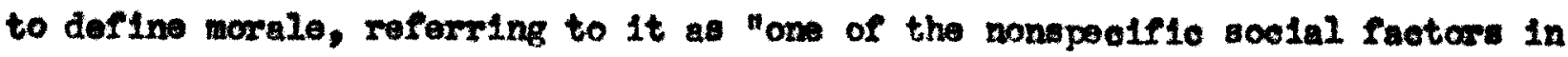
treatwent" (p. 415). Novertheloss, as partleipant observers thoy went shead and studied morale. They conoelved of a contimu for noting ohtfte in worale, ranging from a collaborat1ve level through the cooparative level to the difIntegrative level. They found that different Individuals uabally oould agreo on which lovel was operative in terms of how a given patient or hospital anployee vas carrying out his houpteal role. Uning this teohntque, they were able to recond some sovere Individual and collective diaturbanees whioh arose and galnod montim during the throe wook course of an adminiatrative problow. It is noteworthy that what was orlednally a vtaff conflict over the eoonemis mede of the hospltal as opposad to it therapeutio alms aon affected most, if not all, the womber of the institution. This atudy has been widely pub11012ed and sinilar situation are now rogarded as lllustration of "tho Stanton and Sohwartz offoot." Stanton and Sohwartz's study 18 intoresting and informative, but it is diffloult to evaluate the complotenses and objeotivity of data whioh is colloated by wans of particlpant observation. Also, it is Imposetble to quantify their date for purposes of oomparison with pther group. Finally, thelr study was carried out In one mall ward of a small axolusive wental hospttal, ${ }^{2}$ it is unlikely that they could have ohoeen a more unreprecentative hoepttal and group of subjeote for atudy.

The pubileation afted thus far indleate the extent to which patient morale has bean etudied in mental hospltals. Other studies, whioh will be reviewed in the wocond section of thie ohapter, provide some additional data on this subject, but only indireotily so. The pawolty of studies in this area appears to be a rosult of the conceptual alsagreewent which surounds the 
concept of morale.

Several attempts have beon made to elarify the notion of morale. Sletto (1937) was among the first to think of morale as a composite of meveral rarlables, rather than a single unit variable. He developed a Likert-type worale seale with which he hoped to leolate one or more of these vartables. If reported split-half and testmetest rellabllity coefflolente of .72 and .61 , reapectively, baced on a sample of 50 subjeots. Having obtained higher rellablilty ecefflolents on other personality wcales, which he oonstruated and adinintetered to the same group, sletto conoluded that worale is a lese stable phase of personality than the others. His morale aeale is a highly generallzed one; high morale is equated with optiniem, low morale with peneialow. Although the statemente are phrased impersonally, they are oo obriouly Interrelated and wo highly personal that thoy make respondente aware of what It is that 1s being weaured. Such an awareness oawses rospondents to beocme defonsive and produoes noutral att1tudes. In Slotto's soale, the Prohologloal objeot unier otudy 19, in erfeot, the reapondant hinsele.

In 1940 a group of paychologiots wade another attempt to alexify the term moxale (National Researoh Counoll, 1940). They reviewed the max waye in which morale had been used and proposed three definition whioh they bellewed would be helpful in gulding ruture otudy.

"I. (The IndIvidual-organie omphasis,) The term morale refera to a condition of physical and enotional well-being in the ind1vidual that makes it possible for hin to work and IIve hopofuly and effoctively, feeling that he chares the baele purpose of the groups of whioh he is a nembery and that makes it posatble for

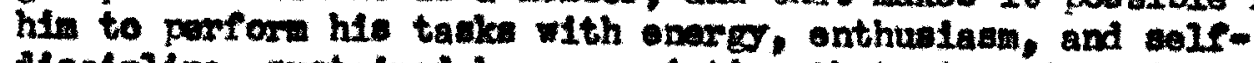
disolpline, wutained by a convietion that, in spite of obetecles and confliet, his personal and soolal ideals are worth purauing. 
II. (The group emphasis.) Morale refere to the oondition of a group where there are clear and fixed group goals (purposes) that are felt to be important and integrated with individual goalo; where there is confidenee in the attalnuent of these goale, and subordinately, confidenoe in the mean of attainmont, in the leaders, associates, and finally in oneselfs where group actions are integrated and cooperative; and where ageression and host1lity are expess sod againet the forese frustrating the exoup rather than toward other individuale within the group.

III. (Buphesis on Individual-within-the-group on any poeifle cocasion.) Olven a certain task to be acocapliahed by the group, mornie pertain to all faotor in the individual's 11 fo that buring about a hopoful and energetio partiolpation on his part so that his offorts onhanoe the effeotiveness of the group in acoompliahing the takk in hand." (National Resoaroh Counall, 1940)

Although these defintions natly coniense the mumorous usages to which morale has been put, they suffer from the 11nitations inherent in any abotraction. Not all studien of morale ean be ald to belong exolubively to one oategery or the other. There is woh overlapping, and individual inveatigators continue to go their weparate ways. They either propose their oun derinitions, or they avold the 1sum entirely. Campbell (2955), for example, studied the morale of several submex In swowe in torns of whioh ware "happlost", but did not farmal120 even an oporational dofinttion.

The moet reoent attempt at olarification of the term morale leaves mush to be dealred.

Morale is to be oonoelved of as a oharacteristle of behavior. Its nature and quality is to be judged against a prototype pattecrn of dynanlo progreasion. That pattern is blologloally and aoolally rooted and determined." (Oxldaton, 1958, p. 257)

This definition of morale, arrived at through the combined efforte of a large number of soeial selentiats intereated in "oomanication," comanioster wo Ilttle by way of weaning and subsuwe so wweh that ono can wee why noxale has not becowe a matter of general ooncern to perohologlets ch ch1ld (1941) long 
ago had hoped it would. One writer (Roethlisberger, 1949) has expreseed hope that in time the terw morale w111 drop from the vocabulary and that in its plave will be subotituted effootive elassifleatlon of human situations and skillful mothoda of handiling theid. Moralo studies contims to be reatricted to apelal groupe, primarily Industrial workers (Baehr, 1958, Gulon, 1958) and armed foroes perwonnal (Learner, 1954, Tooh, 1957, W12linghan, 1958).

Mollemar (1946) has proposed an ambit1ous progran whoroby, he belleves, onder could be brought into this fleld of researoh. Besteally, he weos two thing whioh need to be aooomplished. "the determination of the dimenatons of morale and the conotruotion and validation of coales for moasuring these dimenalon" (1946, p. 365). Hollowar proposes atarting with carefully defined posturated somponents of moralo, construeting unidimensional seales for measurIng thew, and using otratifled campling prooedures for deternining intermacule correlatione. Than, faotor analyeie techniquss oovid be used to determin the number of factore underlying the varlous aspets of morale. Finally. Mollowar recommends the oonstruotion of soales for measuring the obtalned factore, relidity studies, and reacarch desigaed to unocver the peyohomootal correlates of the coveral morales,"

The prevent study is conournod with the firat two aspeots of Mollomare proposal. A unidimemional seale was conatrueted in an effort to weavure one oomponent of norale In the peyohiatrio hospltal. Favorableness of regard for the ward was postulated as being oomponent of morale in this sotting. High morale was equated with a favorable attitude toward the ward and lon morale with an unfavorable attitude toward the ward. This we of the term morale 10 otmilar to the ons proposed by Cembell (1955) and reforred to prevlowaly. 
It 10 explieft in comperieon to, for example, the one proposed by caldation at a1. (1958), and It londs 1taelf to ompirioal Imvatigation whereas the definttions of moralo proposed by the National Researoh Councll (1940) do not. Further, this nostulate makes possible the construotion of unidimensiomal attitude cale which in 1 to developmental stages oould inolude statements dealIng with the kinds of Interpersonal relationshipe whioh Klemee (1951), Miohala (1947), Todd and hittkower (1948), and Stanton and Sohwartz (1954) refor to when they atrese the importanee of, but do not define, morale.

\section{Attitande}

In the riret part of this seotion the concept of attitude and mothode for measuring attitudes w111 be discussed. In the seoond part, several studies of the attitudes of paychlatrie 1npatients will be sumaarized.

The conoept of attitude has been a matter of eonoern to soclal solentiste for at least a oentury. Spenoar (1862) is supposed to have been the first "poychologist" to use the term, socording to Allport (1935). Another historian (Cardno, 1955) gathered together the avallable definitions of attitude, found a comon-denominator, "direotionallty," and set about tracing the emergenoe of this concept from pre-experlantal thinking. He aredits D. Defoe, the author of Robinson Crusos, as being the first to include affective ocmponents and the oharacteriatio of dirsctionality in describing posture (attitude).

Allport (1935) covere eubsequent developants of the notion of attitude. In reviewing sixteen derinftions of attitude, he found that preparation or readiness for response was an essential oharaoteriatio of them. Henoe, in formulating a definition of his om, attitude became

"a mental and neiral state of readinass, organized through 
expertenoe, exerting a directive or dynamio influence upon the Individual's reaponse to all objeote and altuatione with which it is related." (Allport, 1935, p. 810)

A few yeare later Helson (1939) reviewed and cxitlolzed definttions of attitudea from thirty sources. Awong thope definitions he found twenty-three charaoter1zations of att1tudes.

11. Organio drivea.

2. Purposes.

3. Motiven.

4. A "oore of affeot."

5. The emotional concoment tante of aetion.

6. Peruanentiy felt dispositions.

7. A speilal case of pre-disposition.

8. Cenerallesd oonduot.

9. A nural set. A Nouromuscular set.

10. A tabllized sot.

11. A state of readinoss.

12. A dispostion wodirying ar1oing experienoe.

13. Verbal reaponses for or againat a peychologlosl objeot.

14. Soatally connelled behavior of an enduring type.

15. A response whioh is more obviouly a runotion of diepoaition than of the imadiate stimulus. 16. The result of organization of experiance.

17. A direotive or dynamile influenoe on the respones to

which relater.

18. A determines of the direation of an activity.

19. A guide for onduot. A polnt of referenoe for new experienoe.

20. A trial responae-substitute behavior.

21. A way of ooncelving an object. A posture of consclousnoss.

22. "A sum total" of inolinations, foelings, notions, ideas,

fears, prejudices, threats, and oomvietion about any srocifio tople.

23. An 1ntegration of the speafle responses into general set." (NeIson, 1939, $p, 380$ )

He recognized that some of these oharaoterlations are duplicates and others are so general that $t$ elr inolusion under the tora attitude would not faollitate underatanding. Henee, he eliminated oowe of the oharacterizatione and formulated the following defintion.

"An attitude may be oonsiderad a felt disposition arialing from 
the integration of experlence and innate tendencles whioh disposition modifios in a general way the reaponses to paychologioal objeots." (Nolson, 1939, p. 381)

Nelson's definition is almost an equivalent of Allpont's, suggesting that no one, Inoluding Helson, had been able to add anything of Impontance to the coman eloments whioh Allport oullod from the olxtoen definitions he reviewed and upon which he baeed his definition.

In reeent yeara a muber of definitions of soolal attitudes have been proposed. Kreoh and Crutehfield define attitude as

"...an enduring organisation of notivational, exotional, perceptusl, and cognitive processes with rospeot to some aspeot of the Individual's world," (Kreoh and Crutcheleld, $1948, p, 152)$

In a similar veln, CampbelI (1950) has offered this definition of attitude "An Individual's soolal attitude is an onduring ayndrome of response consistency with regard to (a set of) soolal objects." (Campbell, 1950, p. 31)

In all of the derinitione whioh have been presented and in others whioh have been or are ourrent in American aocial payohology, there is an Implied or expliolt exphasis upon readiness to respond. One can treos this emphasis through Allport, the physlologloal experiments he reviewed (Allport, 1935), the British asoolationiste, and even to Roblnson Crusoa!

The oonopt of attitude is currently regarded as a hypothetioal or latent variable whioh refers to a large number of related aots or responses (Stouffer at al., 1950), although there is a lzeable contingent of soolal solentiots thet views it otherwise (Duijker ot al., 1961). The theme that the eonoept of attitude is a consistenoy anong reapones to apecifled set of stimuli, or soolal objeots, implies that an attitude governs, or mediates, or prodiets, or 
Is shown by a variety of reaponses to specifled atimul1 (Creen, 1954, pp. 335336). The Iatent attitude is defined in terws of the corratations whioh oxist between rosponses, and covariation among responses is associated with the varlation of an underlying variable. This theoretioal framework makes pousible the equating of an attitide with the responses which oonatitute 1 .

Attitude measurement, then, requires the obtaining of statements, or as they are scuetines called, questions, that will represent in a partionlar weale the olass of all possible statements that oan be made about the peychologieal objeot of Interest. It is necessary to as gume that there will be differences in the bellef and diebellef systems of roapondente with favorable attitudes toward the obfeot and reapondente with unfavorable attitudes. Statement: that are factual or that might be peroefved as faotual belong to one subclass of otatenents that is elininated from the pool of potential statemente beeause of the poselbility that they are equally likely to be agreed with by respondents with favorable attitudes and by those with unfavorable attitudes (Bdwards, 1957).

A collected set of potential statowenta for an attituie scale may be oubaltted to a group of judges who are asked to rate the degree of favorablenoes or unfavorableness indicated by each atatement. The soale valuen of the statements on a poyohologleal continume are obtained on the basis of the combined ratings and used in wooring the responses of subjects to the statemente. The mothode of paired comparieone (Thuratone, 1927), equal-appearing Intervale (Thuretone and Chave, 1929), and successive intervale (Homar, 1930) Imvolve the utilization of judges and provide seale valwes for each statement of the attitude sealo. 
An attitude scale may be developed by submitting a set of collocted ststements to resmondents and requestine them to indicate the extent of their apreement or disagreoment with them. Those statements which are most effective In differentiating betweon responients with favorable and those with unfavorable att1tudes toward the object are retained in oonstructing attitude scales of the summated ratings (Likert, 1932) and cumblative (Guttman, 1944) types.

Bdwarda (1955) and Bdwards and X1lpatrick (1948) have proposed teoh-niques for the construction of attitude scales that involve both soaling and response nethods.

Other poychologioal soaling wothode for assessing attitudes have been proposed and are being developed, but have not been used in developing attitude soales to the extent that the methods outlined above have. Aleo, methods of direct questioning, observation, partiolpant-observation, and rating seales have been used in investifgating attitudes, but not to the extent that unidimensional attituie soales have efther because they require axtensive time or beceuse thay produce results phich are of qustionable objectivity and complete ness.

The nethod of summeted ratings wes chosen for developing and constructIng the attitude scale utilized in the present study for several reasons. It was thought that this mothod would be simpler and easier to apply than the methods which imvive use of a judging group, a prosumption whioh is no longer belleved to have been accurate. Seoond, Thurstone's (Thurstone and Chave, 1929) assusption that ratings of attitude statements in the method of equal-appearing Intervals are Independent of the attitudes of judges has been contradioted by experimental ovidence (Jpsham, 1962), ouggesting that method which involve 
judges might eliminate as "ambiguous" cortain potontially disoriminative statements before respondents had an onportunity to rate then. Phird, following McNemar's (1946) auggestion, it seemed that a combination of the atumated ratings method an an spropriate scaling techniqu would rroduce an attitude scale which would be better than one based on fther mothod alone.

\section{Related Studier}

The attitudes of peychiatrio innatients toward various aspects of mental hospltal have been investigated by several students. Hatch (194:) Interviewed 100 patients, primarily from convaloscent wards, regarding their attitudes toward certain features of the hospital systom. She uncovered distresses and discomforte imposed by the hospital system which patients had found difficult to communicate through regular channels. Her indings did much to stimulate the modification of the pattern at Boston Psychopathic Hospltal. It is diff1oult to evaluate the objeotivity and onnoleteness of Hatch's findings because they were obtained by weans of interview. Her data are peouliar to the setting In whioh they were gathered and diffloult to quantify for purposes of compar18on.

Soublem (1955) was aimilarly interasted in learning how psychiatrio inpatients feel about mental hospltals. She surveyed the literature and found no soale of attitudes toward mental hospltals and no study on the attitudes of mental patients toward mental hospitals. She apnarently overlooked the Inquiry of Hateh (1948). She developed an equal-aprearing Interval attitudo scale toward mantal hospitals, following procedures outlined by Thurstone (1929). She aprled the scale to two samples of male mental hospital patients and found that patients on admission and aotive convalescent pards expresaed 
signifleantly more favorable attitudes than petients on chronte or seniconvalescent wards. No sipnifloant differences were found anong attitude scores of pationts in the varlous dispnost1c oategorles; betwen attitudes and patients' ages; between the total samples or between comparable wards in the two hospitala. Also, the correlation of langth of hospltalization with attitud soores was not signifloant. She recomended that further investigations of attitudes be directed toward other varlables, one of them being the ward situations themselves. She thought that an attitude scale wuch as hera uight help hospltals assoss patient morale.

There are several bastc differences betweon Sovelen's Investigation and the present study. Souelon pas interested in patient sttitudes torard "mental hospltals," a more generte paycholoptcel object then "the ward," which is the beslo untt in the organizational structure of most mental hospitals. Henoe, all but two of her 72 statements contain the words, "mental hospltal(s)", and they have 11 tile to do wth the inter-patient and ratient-stafe ralationshino which are basio elements in the total millou of a ward. She amearentiy used the intultive mothod in mitine her statoments, rather than colleoting them by eanirioal methodal perhaps, this is how she came to ovarlook the innortant subclass of interporsonal relationshipe. Her "irrelevant" items were elininated by judges without ever having baen aduinistered to test their discriminatory value. The Likert method (Bdwards, 1957, Likert, 1932), used in constructing the attitude seale for the resent study, is better sulted for the empirloal testing of a statement's discriminatory powex.

Rlopfer, Fylie, and Hilison (1956) attempted to determine whether groupa may be distinguished from one another in terms of their overall attltude toward 
mental hospitals, as well as their mrticular attitudes toward mental hospttals as derived from an item analysis of the Souelem soale. They administered Souelen's scale to six groups of subjects who seemed to have varying degroes of familiarity wth a mental hospltal sotting. One of these groupe onsisted of 33 psychiatrio inpetients, 17 being on an intonsive treatment servioe and 16 on chronio wards. The other expup conslated of clerieal ennloyees and ward attendants. The investigators found that Sovelem's sorle can distinguish certain non-patient groupe from one another. With respeot to the patienta, a compariaon failed to reveal any signiflcant differences between the two patient groups. The latter finding is not surprialing; the patients were on different. wards, for that matter different kinds of wards, but they were all in the same hospital and they were agreeing or disagreeing with general statesents about the mental hospltal, not about wards. In faot, the statements in the Souelem soale are so phrased that they can be adminiatered to elther patients or nonpatients. The patient grour had generally unfarorable attitudes, a finding which differs markedly from the favorableness of attitude whioh Souelem found In her natients. This difference probably stems in part from Souelem's not having tested anonymously.

Libo (1957) has dovelopod an instrument for measuring patient-therapist attreotion. Ho uses four "ploture impressions," whioh deplet patienta and theraplats in various stuations, as an instrument for eliciting patient attitudes. The anount of attraction in the responses to each card is quantitatively determined and the length of time a patient 111 romain in therapy is mredicted. Ifbo's plotures are, at best, rough sketches, and his presentation 18 lacking in evidenoe. 
Caudill (1958) used twelve "ploture interview" oards in assessing the patterning of attitudes in a small, rrivate nsychiatrie hospital. He was interested in the att1tudes of dootors, nurses, and patients toward the hospita. In general, therapy, adininistration, and human relations. Hia platures deplot both Intra-role and inter-role group activity in the hospital. Thirty-nine subjects, including elghteen patients of both sexes, were ploture-interviewed at length and scored on 723 toplos. The toplcs were rated as being either ontimistio or nessimistio, and then oomparisons were made within and between the various role groups. Among other things, Caudill found that all role group were in agreement about the inadequate natime of the hospital in general, that therapy was seen rather hopefullys and there was no general agreement regarding administration and human relations.

Candill mentions that he did not interview all of the petienta and personnel in the hospital, but he says nothing about how he seleoted hls sampla One can only infer that he studied ocoperative subjects, that the representativeness of hie sample is questlonable, and that his results are biased. Purther, his rolo-group samples are 00 small-five doctors, five residents, ton nurwes, elght male patients, and ten fomale patients--that it is diffloult to deternine the signtfloance of the reported dfferenceas they could easily be attributed to the operation of chanee. Tendenoles toward optimialin and pessivis in the various types of interactions are presented in numerous tables, but because of the IInItations mentioned, I1ttle importanoe can be attached to then.

Reanikof, Brady, and zeller (1959) recognized the serlous 11nitations inherent in previous investigations of the attitudes of patients and hospltal 
personnel. They were intereated in making a more systematic study of the inPluence of attitudes on the bohavior and clinical course of the patient. Foewe Ine their interest on the peyohlatrio hospital, the paychlatriet, and payohlatrio treatwent, they developed a battery of procedures for ellolting attitudes In these areas. The battery consibte of four instrumentst the Sovelem Attitude Seale (Souvien, 1955), a Pleture Attitudea Teat; a Sentenee Completion Attitudes Test, and a Multiole Cholos Attituden Questionnalre. This publieatio contain weoring proedixe and wellabllity data for the Ploture Attitudes and Sentence completion teets. These date are roported in terme of the amount of the Inter- and eolf-agreemont ohown by judges in sooring the teste. Tho statietioal algnifloanoe of the reported poroentages and correlations is not given although the correlations appear to be highly algntfloant. Also, no evidewoe Is given regarding the extent to whioh ropoated messuremente with the teats yleld sinflar reaults, honoe the dependablilty or rellability of acores obtainod on the wealuring instruments romaln unknown. Further, the authors state that it is posatble to osloulate a total score in each of the three attitudinal areas oovered by the Sentence Completion Teat al well as a oombined overall soore, with low scores Indloating postive attitudes, and higher soeres rePlocting Inoreasingly negative attitudea $(p, 264)$. In offect, the authore are assuming that the inociplete sentenoes in one area are meaturing an attitude towand one paychologloal objeot which 18 different from the attitudes being weacured by the sentences in the other two areas. However, nothing is known regarding the interdepandenos of the eantenoes in each area or the relationahip of the sentenoes in one area with those in the other areas. Reanikoff at al. did not investlgate the roliability of the Multiple Chotes Attitudes quedion- 
neire and the Souslem Attitudes Soale because, for them, rellabllity refera to rellability in sooring and these instruments are scored in an objeotive manner. Hence, the authors assume that thase ingtruments maetre the varlables they were designed to measure when 11ttle is known regarding the accuracy and atablilty of soorea obtalned on thea. In brief, It appears that additional data should have been gathered before ooncluding that the procodures have been ohecked for reliabil ty and found to be adequate. (p. 266).

Brady, Zeller, and Resnikofe (1959)-used their Psyohiatrie Attitudea Battery in an attompt to determino whioh, if any, attitudinal faotors are related to the outcome of peychiatrie treatment. The battery was used to assese the favorableness of patiente' attitudes toward the thee interwelated areas mentioned provionsly. Favorableness implied the degree of trust and eonfidenoe a patiant indloated, implioitiy or explieitly, in peyohiatrio treattaent, or the degres of ocmpetence and intorest he attributed to the dootor or hospital. An elght point "Degree of improvenent rating soale" was developed for the purpose of estabilahing a base lins during a patient's firet woek of hospitalIzation and for reoording the degree of change during the oouree of treatenent. A heterogenous group of 142 patlente wore aduiniatered the battery auring the Pirat two weoks following adulsaton and rated by their therapiste from four to alx wonthe aftor admission. Relationohip botween various attitudes and the outoome of treatment and the contribution of baokground factors were deternined. Analybis of the data revealed that favorableness of attitude, as meatured by the sentenes completion test, bore no signifloant relationship to thorapeutio outecme, but farorableness of attitude, as mosured by the autiple ohotee Inotrument an the Souelem seale, was algnifloantly related $(P<0,05)$ in both 
ares, to outcome. The ploture test resulta did not lend themelves to quantifleat1on, but the Imvestigators inferred attitudes and otudied their rolationship to therapeuttio outoonas among other signteloant findinge, a marked degree of association $(P<0, \infty)$ was found botween peroelving the hospital in a supporting, protective, or nautral mannor, rather than as oold os menaolng, and having improved in treatbent.

It Is noteworting that Reznikoff at al. developed their battery in oxder to wake a more systenatio study of patient' attitudes, yot the greatest share of their rosults is based on data obtalned from the Ploture Attituxies rest. In thoir firat publioation, they had orltiolzed this kind of datum as being almost impossible to quantify for Individusl and group comparisons. Their sentonoe completion test, also diffleult to sooro and quantify, produced no 6Ignifioant resulte. Their multiple oholoe teet seses ouporfiolal and does not akk questions in the areas, 11ke the ward, which noed to be explored, further, It is based on the aetting in whioh it was developed and it takes things for granted which do not apply or coour in large publio hospltals. The oxitiolea made proviously of the Souvion soale apply here as well. In spite of the IIaltation Indiested hero, the Plndinge of Brady at al, underline the relationship of attitudinal factors to therapeutio outcome. Thoy defins favorableness of attitude and they atress the importanos of high morale in the peyohiatrio treatment setting. Their study contraste sharply with the unsystematio prom duations and anoodotal socounts of others referred to previously.

Wolfonberger (1958) Invertigated the attitudes of aloohollo petients toward mental hospltals. Ho was interested in learning whether age, education, treatment, and provent or previous hospitalisation are lated to these att1- 
tudes. He adminiatored the Sovelom acale to 95 nemly admitted poynohietrio patlents, 36 of whon wore alooholios, at a state hospital. The patiente were divided into three grouper a group who had had no arovious poychistrie inpatient oaro; a group with prior oonfinement in a peychiatrio ward of general hospitals and a broup with prior confinement in a bona fide mentel hoopltal. Age and aciucation were ruled out as vitiating rariablos when correlations botwoen them and scores on the Souslem sosle were found to be non-signifleant. Aleoholles were found to hold a Ignifloantly more favorable att1tude towand mantal hospl21s than non-aloohollos ( $P<.001)$. When the seores of seven aloohollos who later escaped from the hospltal ware oompared with those of alooholie non-esoapees, the esoapees were found to have had a algnifleantly more oritieal attitude tofard montal hoepitals than the othere. Non-aloohollo patients with no previous hospltalization did not differ alguifiontly in their attitudes from those who had spent some tin peyohiatrio waxds of general hospitals. Patients who had been hospltalized previousis in a mental hospital showed a signifiontly more favorable attitude than those in the other two groupu. On the basis of the sigmifleant difforence in soores found between alochollo esoapes and aloohollo nonascapees, Wolfensberger ventured that one oould probably compute a regression pquation whtoh would prodiet with acme acouracy whother or not an alooholio rould elope from the hospital. This auggestion weoms to assume that the bohavior whioh hav beon classiflod into two oategorias, oscaning and not escaping, ban be thought of as beling norrally distributed over a graduated seale or continutm. This assumption appears to be unwarranted beoause the dichotonous plassification made is an "elther-or" kind of aplit and not a two-oategony olacsifioation, Itke athlotio-nonathlotio, where reforenoe is mado to 
a trait whioh can be oonoeived of as being continuove and normally distributed. Bven if it were posalble to aceept Wolfenmberger's anauption, it would be necessary to develop a mothod for meseuring this trait in order to oaloulate the correlation between it and the attitude varlable frow which the regreasion equation would be derived. And a high oorrelation between the two sote of moasures would not necessarily insure scouraoy of prodiction unless the var1ability of the meacures was sall. Also, it is vell known that oorrelation ia of most benefit in predioting the performanoe of groups and lo usually of littl holp in foreoarting aocurately what an individual oan be expeoted to do. F1nally, It that the point bi-berlal method of correlation is the one whioh Wolfonberger should have roomended, although point bi-verialo r's are lower then bi-serial r's and are not directly ocmparable to them or to produet-moment comelations; also, validity indexea obtained by the point bl-aerial ocoffielen of comelation are lower than thowe obtalned by the bl-serial oouffiolent of complation. (Gamatt, 1953, p, 362).

Inere and Wolf (1962), In a subequent study, found no ulgnifloant difference between the Sowelem scale soores of alooholle olopere and aloohollo non-alopers. This finding was baed on the soores of flfty-three malea hospltalized for alcoholism, twenty-three of whon oventually eloped from the hospital. Imre and Wolf also Invertigated the attitudes of a group of asployees of a state nental hospttal, a group of atudent nurbes, and a group of nonalcoholle patients. They found no signifleant differenoe between the wesne of males and fomales in the employee group, although the females showed a algnifleantly greater amount of varlability. Among the student nuraes, about half of whow oompleted the Sowelem soale under a condition of anomprity while the 
remainder ldentifled themselves, no signifleant difforenoes in attitude were obtained. No signifleant differenoes were found batwoen the attitudes of male and female pationts. When the mean soores of the four major groupe were oompared, algnifleant differences were found between hospttal personnol and non-aloohollo patients and between alooholle and non-aloohollo patiente, the non-alooholis patiente being lese favorably dispowed toward mental hospltals than either of the other groups.

It Is notoworthy that Inre and Folf found no algnifloant differenoe between the Sovelen scale scores of alcohollo elopers and non-elopers, findIng which contrasts with that of Wolfensberger. Also, Klopfer at al. (1956) found no signifloant differenses between the Sowelem soale socres of poyohtatrie patients on intensive troatment and omronte wards, whereas Souvlea (1955) did wth ocmparable groupas also, Klopfer'a patlent group had generally unfararable attitudes, while Souelem's patlents showed a farorableness of attitude toward mental hospitals. These conflieting resulte may have arisen from real differenoes in attitude on the part of the various groups atudied, elthough the proviously mentioned fallues of the Sowelom soele to dintinguloh group which on an a miost basis were expeoted to have differanoes in attitude ouggeste that the contrauting results way have been dwe to chance errora In masurement. The Souviem soal has been aubjeotod to only ono known rellability atudy in whioh 1t was found to have an equivalent-form reliablifty of .88 based on a oorrelation of the two forms of the acale (Sovelen, 1955). Creen (1954) has polntedout that if equivalence is measured by correlating two equivalent soales, additional evidenos of homogeneity is necessary bovause it is poselble for two highly ocrrelated parallel sosles not to be homogenoous. Honoe, further 
evidence of the scale's homogenalty and untdinensionality is needed before imvestigators an asume that poople with the ane soore have about the same attitude toward mental hosptals.

An attennt has been made in this chanter to provide a reviev of some of the publieations which are basic or related to the mesent atudy. Several

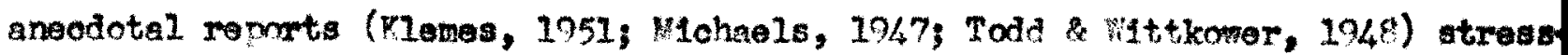
Ing the relationship of norale to tharapeutic outcome in the psyohiatrio hospital and one desoriptive account of the breakown of morale in a mental hospital (Stanton Sohwartz, 1954) wero cited and ovaluated. It was noted that there was a racity of stuiles dealing with morale in this setting, the major1ty of such studies being focused on the morale of industrinl workers and armed forces nersonnel. The onneeptual disagreement surrounding the conoept of morale and the attempts at clarifleation by several rarties (Slotto, 1937; National Research Counc11, 1940; Ch1ld, 1941; Gladston at al., 1958) as well as Molemar's (1946) emplrienlly sound nroposal for beinging oxder into this arsa were revlewer. In keoping with the elrst two aspocts of Mevismax's plan, favorableness of regard for the ward was postulated as being on component of morale in the paychiatrie hospital in much the same way that Campbell (1955) poetulated "happiness" as being an indleant of the morale of submarine orews. Further, a unidinensional attftude scale was proposed as the mothodology for assessing this variablo.

The conoent of attitude was discussed, and a brlef resume of its origins was mesented. It was noted that there is an implied or explicit empasis upon readiness to respond in the repertoire of ourrent American definttions of attitude. The peedominant tendency to regard attitide as a hypothetioal or 
latent variable and to dofino it in term of the correlations whioh exist among responses to a anoclfled set of stinuli, or scclal objeots, was mantioned by way of inlieating the rationale for masuring attitudes. Some of the asamptions underlying the developnent of attitude acales and various mothods employed in construotine then wore discussed. Varfous rossons for selecting the method of summated rating as a technique for deviloping the attitude scale mere presented.

Finally, several studies of the attitudes of psychiatric patients were evaluated orftioally. The investigations by Hatoh (1948) and Caudill (195e) were fooused on attitudes toward various aspets of particular mental hospitals: In each esse the data were obtained by interview mathods the objectivenesa and conpleteness of which 18 questionable. Further, their results are pecullar to the settings in whioh they were gathered and diffioult to quantify for purposes of comparison. Wost of the other studies of natiants' attitudes (Soualem, 1955; KIopror at al., 1956; Roznikoff et al., 1959; Rrady at al.. 1959; Wolfensberger, 1958; Inre and rivolf, 1962) are focused on the attitudes of psychiatrio pationts towand "bental hospitals" and utilize as thoir methodology for assessing these attitudes the scale dovelopod by Souelen (1955). Although credit was given to Souelem for auggesting that an attitude sonle such as hers might be usod in assessing patient morale, aeveral orfticioms were loveled agalnst her scale. First, none her statomenta deal with any $k$ ind of Internersonal relationships, an aspect of life in mental hospitals that must certainly constitute one of the subolasses of statements within the universe, or olass, of all possible statements that can be made about a mental hospital. This anlssion, plus the lack of contradictory evidence, suggeats 
that Souvlen relled unon her Intuition in writing and selecting statemento for her soale, a cusstionsble and unreliablo procedure. Also, the fallure of Soulem's scale to distinguish groups which on an a Detorl basis ware expected to reveal differences in attitude and the paucity of oross-validational findInge ralsed doubts regarding the usefulness of the Souelem coale.

In sumary, a review of the literature cealing with the morale of psyohi atric inpatients indicated the noed for a more systematic means of investigatIng this important variable. The literature dealing with attitudes and their measurement revealed several ways of oarrying out this inveatigation. And mrevious studies of patfent attitudes elther were fooused on different psychologieal objeots or employed methods and procedures which have sarlous shortoonings. The nod for a rellable and valld moans of assessing the attitudes of psychiatrie patients toward their lawediate trestment settings, their wards, was indlcated. 


\section{DBSTCN OF THE RESEARCH INSTRTMEHT}

In the mresent atudy, the term attitude is dafined as "the degres of positive or negative affect assooiated with some reychologieal object" (Thuretone, 1946). The paychologleal object of Interest is the ward of the payohiatrio hospltal, and attention is focused upon the attitudes of pyohiatrle inpatients toward their hospltal wards. The present chapter deals with the developwent of a methodology for ellofting and assessing these attitudes.

The waxd ia the basic unt in the organlzatinnal otructure of nost mental hospttals. Fhysically, 1 t encompases a certain area of spece in ono of the buildinfs or oottage whioh make up a mental hospltal. In some hospltals there are two besio kinds of warda, those whioh are designated as adaission or aoute intensive treatment wards and those which are referred to as chronio or continued treatmont wards. In other hospitals, such as the one in which the greater part of the Iresent study was conducted, no such distinotion is made; rather, warde are distingulahod from one another in terws of the amount of freedom afforded the patients living there. Hence, there are "looked" or "closed" wards and "open" or "full priviledge" wards in the latter kind of hoepital. Paychiatrio wards may vary with respect to bed-oapacity and personnal patient ratio, the open wards tending to havo more beds and fevor personnel per patient. Aloo, they may differ in terms of general treatment procedure or purpose, some wards being primarily custadial wards and others being more 
therapeut1oally oriented. However moh one ward differs frow another in teras of size, ourpose, or pationt population, all psyehiatric wards consist of neople who intergot and oomwinicate with one another in varying degrees.

Then a nationt is assignod to one of the wards of a payohiatrie hosptal he enters altuation which will become the primary locus of his existenoe for an unoertain perlod of tine. The ward becomes a kind of home-away-from-home In which he sleepe, reoelves medication and other treatment, and "belongs" unt1l his behavior warrants his being discharged or transferred. The patient becomes a nember of the groun there whether he interacts and conmuntoates with the other members or not. As a result of his experiences on the ward, the patient typteally develops a general inpression of the ward, depending on the degree to which he feels his needs are being agtisfled and the degree to which he reoognizes that his satiafaotion is a funotion of h1s mesent situation. Paychiatrio pationte frequently discuss among themselves and cocasionally with hospital personnel the rolative nerite and deflolenoles of vards with which they are faniliar.

The present researoh was uniertaken in an effort to unoover the spocifte ovents and sttuations which contribute to the formation of a general impression or attitude toward nspohiatrie wards. In order to obtain data which would be romesentative of the olass of all possible affect that oan be assoclated with a ward, it was necessary to ut11ize and develop methods of investigation whioh vould stimulate and permit the spontanoous expression of both positive and negative feelings. Open-ended interviews and sentenos oomiletion forms are methods which other investigators have used suecessfuliy in rrevious studies of this kind (Howard, 1956, Thurstono \& Chave, 1929; Hebb \& Kobler, 1962; 
N1lingham, 1958). Also, It was thought that the literature dealing with mental hospltals and the mintes of patient-oounoll weetings might contain information regarding events or situations on peychiatric wards whioh conoern patients. Although it is diffloult to quantify and compare data obtained by the above mothods, It is possible to use these date in oonstruoting an attitude sosle. An attitude coale consisting of statenents obtained from such data would not be vulnerable to the critlelams which have been leveled against soales made up of intuitively written statements (Mollemar, 1946), and an attftude soale, by Its vory nature, maks quantifieation and comparioon of results possible.

\section{Derwlorment and Construntion of the Attitude Soale}

An attituide soale consiats of a serles of statements about some peychologloal object. Essentially, it is a questionnaire designed to ellolt the verbal attitudes, or opinions, of people toward some person, rlace, or thing. An attitude seale should be devoloped and construeted in suoh a way that its statenentis are representative of the class of all possible statements that ean be made about the poyohologloal objeot, that 1s, they hould be representative of the universe (Bdwards, 1957). Further, the degree of covariation among the statements should be suoh that they are highly interdependent, or homogeneous; that is to say, the analo should be unidimensional and rollable (Creen, 1954). The following techniques were employed in an effort to obtain representative and Interdepement statements for the proposed attitude scale. Collection of Statarants for Attitude Soale

Four basio aprroaches were ut1lized in pathering statemente for the attitude soale. 


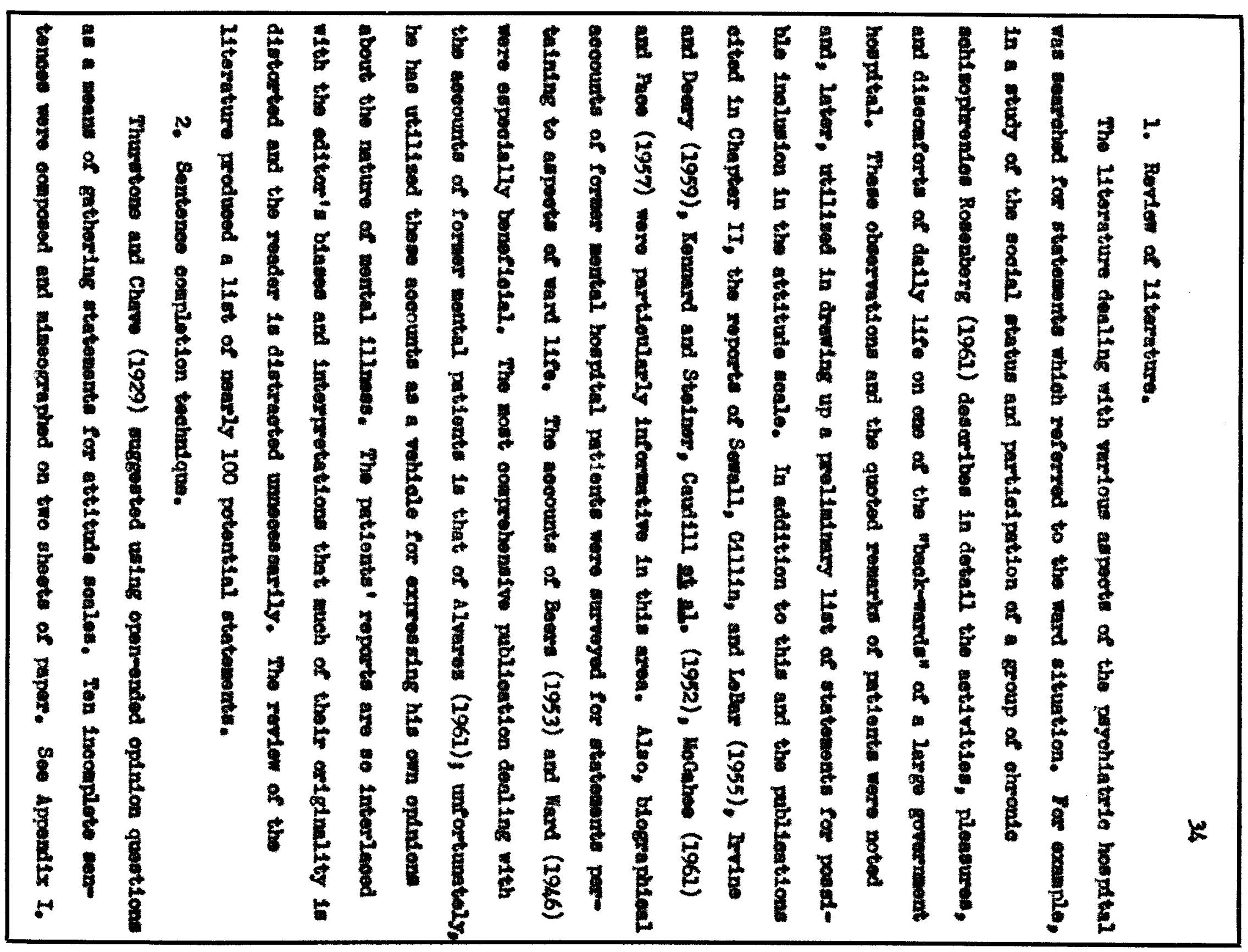


This form as adnistered to 112 psyohiatric incatients on six open and rive locked wards of the Downey Veterans Arininistration Hospltal. Fach of the four psychiatrio units of the hoaptal was represented by at least one rand. An attempt was made to adminiater the porm to all of the patienta on these waxds, but this was not always possible. There wore patients who were away fron the ward for various reasons, and there were natients who ore ther unablo or unwliling to complete the sentenoes. On one ward a patient who was an offleer of the bullding's patient-oounoll expressed his dissatisfaction with the form, stating that it would not be of benef1t to the patients, and all but one of other patients mosent refused to oomplete it. On another, fifteen of the twenty avaliable patients refused to cooporate in splte of the enoouragement given them. On the other hand, when a patient-leader agreed to copperate, most of his fellow pationts gradually followed sult. For exampla, the chatran of the patient-councll on one fomale ward was enthused by the potontial benefite of the profeot, snd twenty-four of the thirty patients on the ward completed the form.

An analysis of the sentence completion forms revealed 1,168 separate responses. They were spread ovenly over the ten santences, there belng no fower than 111 and no more than 123 responses to any one statement. The responses were grouped according to simllarity of ontent. This arrangewent of responses made it possible later to seleot those completions which were most representative of an area and whioh were clear and concise.

There was considerable variation in the quality of the rrotocols. There were single and mult1ple rord, humorous and pathet1o, symbolie and conorete, pertinent and inrelated, and incomprehensible responses. In general, the 
responsea did not lend themeolves easly to quantifleation. One patient Indioated that the therapy program on his ward 1s..." "Chinowe weter torture." And there was at least one patient who folt that the etaff meabers on his ward "shom an undus conseren about their jobe, to the affeot that thoy are always handing out asintno quostionnalres."

\section{Openmand Interview.}

Another ompirical wothod ued in collecting statements for the attitude seale was the tape-reconded, funnel-type intervisw. Patlente were asoured beforehand that their rewarke would not bo identifled. They were asked question 11ke. "If you waxe in oharge of this ward, what would you dor" All of the Interviows were condueted behtnd elosed doors in an offles on the ward. The interview with on patient was of partfoular interest becawe of the eoforran wothod used in solootine him. In this ease, the writer developod and had wivographed the following opinton-type queetlonnalres

In your opinton, which one of the wen in treatment on this untt (ward) boths

(1) Know the nost about the feeling of the nen about the wand;

(2) and is beat able to tall what he knows to womeone doing researoh In this area?

Firlte his nawe on this paper and put it in the box. Your oholos w111 not be revealed to anyone.

The questiomalre was diotributed individually to all of the staff nombers and exllootively to all of the pationte on an opon ward Ior priviledged mon.

The rationale for this apreoach atems from an imvetigation by Canpbeli 
(1955) in which he found a correlation of .9 between the ranking of ten submarines in teras of the relative morale by informed, comminicative, nonrepresentative shore personnel and the ranking of the same ships on the basis of morale bellote admintstered to the orews of each. Campbell concluded that the use of inforwed, artloulate respondents in quantitative studies not only may produce finding of valldity and norality, but reduce the time and expenditures involvad in saleoting and contaoting repreaentative individuale.

Five of the elght ataff nembers and ten of the 33 patients who paxticIpated in the above procedure seleoted nationt "B.P." It should be noted that three of the patients wote nothing on the form, that no other patient recelved more than four and one-half votea, and that at least alx other patients elther ohose themselves or signed their names without reading the form. It was predieted that patient "E.P." would receive the higheat number of votes and, without othere knowing, he was interviewed before the election was held. An examination of the interview indicates that this patient both fulfilled the oriterla requirenonts and revealod himelf to be a rather atypleal and nonrepresentative patient.

In general, the tape-reocrded Interviews produced fower responses and Iess varlation than the open-anded sentenoes. The increased protection whioh an anonymous questionnaire affords contrasts sharply with presenoe of a tape reoorder and interviewer.

4. Patient-couneil moetings.

The Anthropology Service of Downey V. A. Hospltal has on flle a large number of transoribed minutes of patlent-oounoll neetings held on varlous wards and bullding throughout the hospltal. These rocords were searched for 
content pertaintng to ward stustions which oonoerned patients. The reoorda contalned numerous complaints about ward prooodures and hospital iffe in general. Also, the milmtes frequently contained plans for ward activitles and speciflo requests of individual ratients. A numbr of patient-counell meetings were attended and notea were made of 1 tems on the agenda which were relevant to the ward situation. Information gained from a perusal of the reinted minutes and from attending patient-counoll motinge was ut1lized in miting statements whloh later were ineorporated in a prelininary form of the attitude soale.

The acoumulated data was complled and classifled. One hundred and fortytwo preliminary statements, covering on or more aspects of all of the toples found in the data, were composed. Thenever possible, the exalt words of patiente wero used. Salting oonsisted in shortenine statoments and in oubstltuting familiar words for abstraot terms or idess. The statements were reviewed within the light of the criteria advooated by Thuratone and Chave (1929), Likert (1932), Tang (1932), and Bind (1940). These oriteria are given below!

1. Avold statements that refer to the pest rather than to the prosent.

2. Avoid statements that are factual or capable of being Interpreted a faotual.

3. Avold statenente that be inter preted in more than one vay.

4. Arotd atatements that are 1rrelevant to the psyohological object under consideration.

5. Avold stataments that are 11kely to be endorsed by almost everyone or by almost no ons.

6. Select atatements that are belleved to cover the entire range of the affective sonle of interest. 
7. Keep the languge of the statements olear, simple, and direot.

8. Statements should be ehort, rarely axceeding 20 words.

9. Bach atatement ahould oontain only one oomplete thought.

10. Statements onntaining univerals such as "all", "always", "none", and "never" often introduoe ambigulty and should be avolded.

11. Words suah as "only", "fust", "merely", and others of a simtlar nature should be used with care and moderetion in writing atatements.

12. Whenover posetble statements should be in the form of a simple sentence rather than in the form of compound or oomplex sentenoe.

13. Avoid the use of words that may not be underatood by those who are to be given the ocmpleted sonle.

14. Avold the use of double nogatives." (Edwards, 1956, p, 13-14).

The statements were then aubnitted to elght paychologlsts. ${ }^{2}$ They were asked to evaluate the clarity and relevanoe of the statements and to rate each statement in teme of thether it reflected favorable or unfavorable regard for a ward. Cn the basis of their judgments and aprraisals, 68 statements were eliminated from the reliminary soale. A oriterion of 100 percent agreemant on the favorableness of atatement was establishod in order to roduce ambleu1ty to a minimu. Six adjitional statementa were the number of favorable and unfavorable statemente an to retain cone data Which otherwise would have beon negleoted. A proliminary attitude scale consisting of 82 atatenents rosulted from this analysis.

In this developmentel phses of the researoh, the ocale was entitled "Ward Rating Sealo," and pationts were informed that it was part of a hospitalwide research mojeot. They were advised that the statenents had been made by other patients and asked to indieate whother they folt the same way about 
their wards. The value of lenowing what pationts honostly thought about their mesent treatment settinge was atrossed, and they were informed that responses to the acele would be reported in aummary statistioal form only. In group administration of the scalo, patients were requested not to sign their mases. In Individual or small group settings, confidential traatment of the results was promised. In all cases, approplate aprreciation was reniered to the patients for their cooperation. The formal instruotinns utilized during this phase of the research can be eeen in Appendix IV. The patients were asked to respond to esch statement in terms of their own agreement or disagreement with 1t. Five alternetive oholos were printod unier each statement: (1) strongly agree, (2) agroe, (3) undectded, (4) disagree, and (5) strongly disagree. Patiente were inatrunted to ohoose one of the live responses. The 82 statements wer mimeographed on six separate pages. The pages were atapled together in varying orders, every page except the first one being pleoed an equal number times in the pare positions two, throe, four, five, and alx. It was thought that this arrangement of the pages would distribute neutral responses, which tend to inorease as a respondent bacomes fatigued, ovar the antire series of statemonte rather than have the majority of them oocur on the latter pages of the rorat.

It soon beoame apparent that the prellninary scale had several signifleant weaknesses. It requirod too muah time to conplete, twenty minutes to a half hour on the average, and it domanced too much concentration from many patients. The form onslated of six mimeographed pages containing 82 atatements. An analysis of inoonulete forms revealed many initialiy adecuate ettempts by patients who apparently become fatigued and olther coased respond- 
Ing altopether or resorted to responding neutrally. There ore other obviously invalid record form in whioh only one alternative, uaually the "agree" category, had been chosen; this pattern may have arisen from a misunderetanding of that part of the instruotions which referred to feeling "the same way" as the patients who rade the statements. Further, the $t 1$ tle seemed to foous attention on rating the ward whioh, if percelved that way, way aocount for a number of neutral reoond in the preliminary study. For the above and whatever other reasons there may have been it was neossary to administer 261 forms before the statistioally desirable goal of 200 complete and ostenaibly accurate reocorda was reached.

The responses of the 200 patients on the preliminary form of the attitude soale were scored by assigning integral weights to each one of the five response categoriea. The ostegories were weighted in such a way that petiente with the most favorable attitudes would have the highest positive welght. Henoe, for favorable or positively worded statements, it was assumed that this is the "strongly agres" category and, for unfavorable or negatively worded statements, that it is the "strongly disagree" category. For favorable statements, the "atrongly agree" category was as 1 gred a wolght of 4 , the "agree" response a welght of 3 , the "undecided" response a welght of 2 , the "disagree response" a welght of 1 , and the "strongly disagres" response a welght of 0 . For unfavorable statements, the soorine gystem was reversed so that, for example, the "strongly diagree" responte was assigned a welght of 4. A total socre for each patient was determined by sumating the integral weighta which were assigned to the oategorles he ohose. The scoring proodure presented here is referred to as the nethod of sumated ratinge (BIrd, 1940); 
Edwards, (1957), or more brieny as the Likert mothod (Likert, 1932, 1937).

In order to construot an attitude scale by the likert method, it is nevesary to obtain statements whioh are cepable of eliciting olear differenoes of attitude towaxd the peycholopioal object under conslderation. It was hoped that an analys is of the dats obtalned in the prelininary study would rrovide 20 to 30 statements of this kind. An 1tem analysis mas porformed by, flrot, arranglng the sumated soores of the 200 petients in the form of a frocuenoy distribution. Next, two ariterion groups were selected, one oonalatine of the top 27 peroent of the total distribution and the other of the botton 27 percent. The top group, or high scores, and the bottom group, the low soorers, esoh Inoluded 57 patienta. Kelley (1939) has demonstrated that the ratio of the obtained differenoe to 1ts standard erros is at a maximum when each of the groups oontaine this peroentage of the total nopulation teated. Finally, tvalues were oaloulated for each of the 82 atatements according to the method proposed by Edwards (1957).

$$
t=\frac{\bar{x}_{h}-\bar{x}_{1}}{\sqrt{\frac{\sum\left(\bar{x}_{h}-\bar{x}_{h}\right)^{2}+\sum\left(x_{1}-\bar{x}_{1}\right)^{2}}{n(n-1)}}}
$$

where $\bar{x}_{h}$

$$
\overline{x_{1}}
$$

$$
\sum\left(x_{h}-\bar{x}_{h}\right)^{2}
$$

and $\Sigma\left(x_{1}-\bar{x}_{1}\right)^{2}$
= the mean score on a given statement for the high roup

= the mean score on a given atatement for the low group

$$
=x_{h}^{2}-\left(x_{h}\right)^{2}
$$$$
\left.=x_{1}^{2}-\frac{\left(x_{n}^{n}\right.}{n}\right)^{2}
$$ 
The obtained t-raluas ranfed from 2.38 to 12.51 for the 82 statements. Edvards (1957) considers any t-ralue equal to or greater than 1.75 as indieating that the average response of the high and low groups to a given otatement differs ignifleantly, provided that there are 25 or more subjects in each of the groupa. Accepting this criterion, all 82 of the atatements on the prelininary form of the attitude soalo can be sald to be capable of elleting clear differences of attitude.

That was desired was a set of twenty to thirty atatements whioh would elloft olear differences of attitude toward the ward. Henoe, the statements wore arranged in rank order on the basis of t-values. Twenty-alght statements were selooted from among the fifty atatenents with the largest twaluse. This number of statoments was chosen beoause this was the aaximin number of statements one could arrange on two sheots of regular ofze paper. The firat 28 atatements having the highest t-values were not aleoted because such a geloction would have reaulted in acale having 12 favorable and 16 unfavorablo atatementa. It is desirable to have an equal maber of favorable and unfavorable atatements in an attitude soale so as to diminteh the chanes of a response set being penerated in respondents. There is another reason why the first 28 statements were not chosen for the final scale. Several of these gtatemonts were so simliax in o ntent, differing only in form, that patients had observed and commented upon 1t. See, for example, statements \#64 and \#68, $\$ 38$ and $\# 60$, and $\# 35$ and \#73. In these cases, the statement with the h1gher twalue wa selooted and the divcarded statenent was roplaced by a statement pertaining to sone other espect of ward life. The latter clinfoal procedure nade it posstble to include some statements which covered areas whloh otherwise 


\section{4}

would have been nelected in a purely empirioal aprrosch to seleotion.

Other methods of ltem analysis have been ouggested and utilized.

Murphy and Likart (1937) welected statementa on the basis of the magnitude of the differenoe between the means of a high and 10 group. They found that this prooedure agreed woll with the ordering of the same statemonts in torns of the magnitude of the correlation between the statement response and total seore. Webb (1958) used the simpler proodure, caloulating a difference value for each statement and selocting for his scale an ocusl numbr of favorablo and unfavorable statements having the greatest difference values.

In order to determine whether the final exoup of 28 atatements conat1tutes a soale and whether they are apropriately distributod on favorablounfarorable continum, the responses of 200 petients were sceled according to the multiple category method (Rtmold1 and Hormaeche, 1955). This method provides a procedure for estimating the modal disoriminal process and discrimInal disparsion of stimult, sall we the wilue of the boundarles of intervals on the oontinum. It 1s based on the law of comparative fudgnent (Thurstone, 1927) and has been applied to the suocessive intervals and graphic rating scale methods. As far as can be determined. Webb (1958) was the firat to amply it to the method of sunmater ratings.

In the multinle catogory mothod, it is as ntmod that the atimuli are nomally distributed and that, together with the interval ilmits, they can be located on the same prychological continum. The origin of the soalo is definad as $\sum_{j} S_{j}=0$ and the unit of measurement as $\left(\sum_{j} \sigma_{j}\right) / n=1$ where $s_{f}=$ the modal disoriminal prooes for the fth stimulus 
$\sigma_{f}=$ the discrininal dispersion for the fth otimulus

$n$ = the total number of stimull

The modal disoriminal prooess (scale value) for each otimulus is defined as

$$
\frac{\left(\sum_{1}-\sigma_{j} \sum x_{1 j}\right)}{m-1}=s_{j}
$$

where $L_{1}=$ the modal diseriminal prooess of the boundary between intervals 1 and $1+1$, where there are intervals

$x_{1} f=$ the normal deriate corresponding to the proportion of times that stimulus $I$ has been placed in a position less preferred than the point LI

And the value of the dieoriminal diaperaion (atandard deviation) for each stimulue is given by $\sigma_{g}$. $\frac{n}{\nabla_{j},(1 / v j)}$

where $v_{j}=\frac{1}{m-1} \sqrt{(m-1) \Sigma x_{1} j^{2}-\left(\Sigma x_{1}\right)^{2}}$

Sumarizing the above, the multiple category method of scaling enables one to determine the standard devlation and sale value for each statement. The stimulus or soale values should sum to zero, and, if the discrinalnal diapersione for all stimull are equal, the standard deviations should sum to unity. It is also posalble to determine the normal devlate welghts for each of the response categories by this method. These data can then be used to verify the integral weight: which were assigned to each response oategory and used in sooring the prelininary attitude soale.

The following procedure was enployed in soaling the data a) Prequenoled and corresponding proportions were obtained for each of the flve response 
categories. These values represent the number of patiente who eeleoted each of the flve respone eategorien for each statewent. They are presented in Appendix II. b) Cunnulative proportions were caloulated for the response categorles (Appondix II), and corresponding norwal deviates were deternined (Appondix III). c) The tandard doviation of each statement was obtained by weans of the forwula prosented above, followet 1) The normal deviate values of the elve response categories for each otatement wore aumated $(\Sigma x 1 j), 11)$ the sane valwe wore equared and summated $\left.\left(\Sigma x j^{2}\right), 111\right)$ vf and INJ ralwe were oaloulated, andi111) the $1 / N \mathrm{~N}$ valves wore suanated for uoe as a constant in the formula for obtalning atandard deriations for each atatewont. (Table I). d) The upper limits of the elve rosponee eategories for each statement were oaloulated by multiplying each nowal deviate ralue the atandard deviation of the atatement. The upper IImit of the extreme ("4") interval was estimated by aseuning that the aubjects who ohose thi category wore nomally distributed throughout the Interval. Henoe, the muerioal differenoe between the nomal deviates for the "4" and "3" Intervale was addad to the normal deviate for the "4" Interval, and, then, this value was mintiplied by the otandard deviation for the statement to obtain the upper lialt for the 1nterval. (Appondix III). e) Nownal doviate velghte for each of the reapones eategorlee were obtalned by adding to every upper lintt value the lowert negative value $(-2,16)$ among all the upper lintt values obtained. This prooedure eliminated negative armbere from the table of nomal doviate weighta and sot the lowest sooring weight equal to soro. f) Finally, soale values were oaloulated for each of the 28 etatements bodifylng llghtly the fozmula presented earlier. The denoninator of the formula was ohanged from 
$\mathrm{m}-1$ to $\mathrm{m}$, the total number of response categorles per statemant, beoavee, as Indioated in $\left.n_{d}\right) "$ and $\left.n_{0}\right)$ above, the upper linit of the extreme interval or reeponse eategory was eatimated and a wight for this limft was oaloulated. Ordinarily, in applying the multiple oategory moth to data obtained by the mothod of subcessive Intervals, the extrene Interval is dropped, henoe the we of -1 in the formula.

As Indloated previouly, use of the multiple eategory method asermea that the stimuli are normally distributed. By defintition, the stimulue values for the varlous stimul should sum to zero and the otandard dorlation, when sumated and divided by the total nuber of stimuli, should aum to unity. The distribution of the aosio value for the 28 atatements of the attitude soale, IIluetrated in PIgure I, Indloates that only nine of the statemente have negative soale values and that there is les varlabillty of soale value anong then than there is for the atatewants with positive soale valuos. Table I indleates that the stialu value do not sum to sero $\left(\sum_{j} s_{j} 2_{2} 8\right)$.

This sinding refloote a tendenos on the part of the patiente surveyed to "agree" with the favorable or postefvely worded statements and to "disagree" with the inferorable or negatively wonded statemente. Refereno to the froquoney oolume in Append1x II w11l doabent this tondenoy. One would surnise that the pationte who oharaoteriotically responded in this annor were elther suffielently satisfled, but not overjoged, with the syoten on tholr wards or they were afrald to oxitiole thalr onvironaente because of their depondency upon 1t.

Table I Indieates that whon the standard deviations for the atatements are unamated the obtained value was approximately oqual to the number of 
Psychological continum

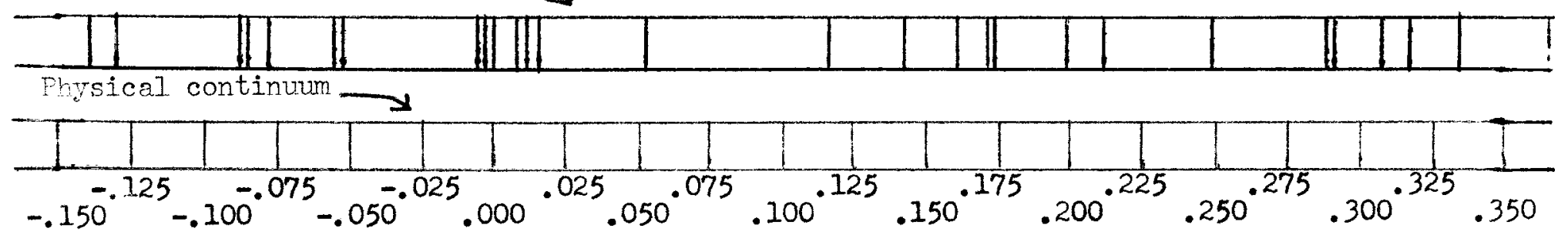

Fig. 1. Distribution of Scale Values for the 28 Statements of the Patients Opinion Poll 
Table 1

Standard Deviations, Scale Values, and Normal Deviate Weights for Statements on the Putients opinion Poll

Normal Deviate Weights

Item Standard Deviation Scale Value $\begin{array}{lllll}n & 0 & 1 & 2 & 3\end{array}$

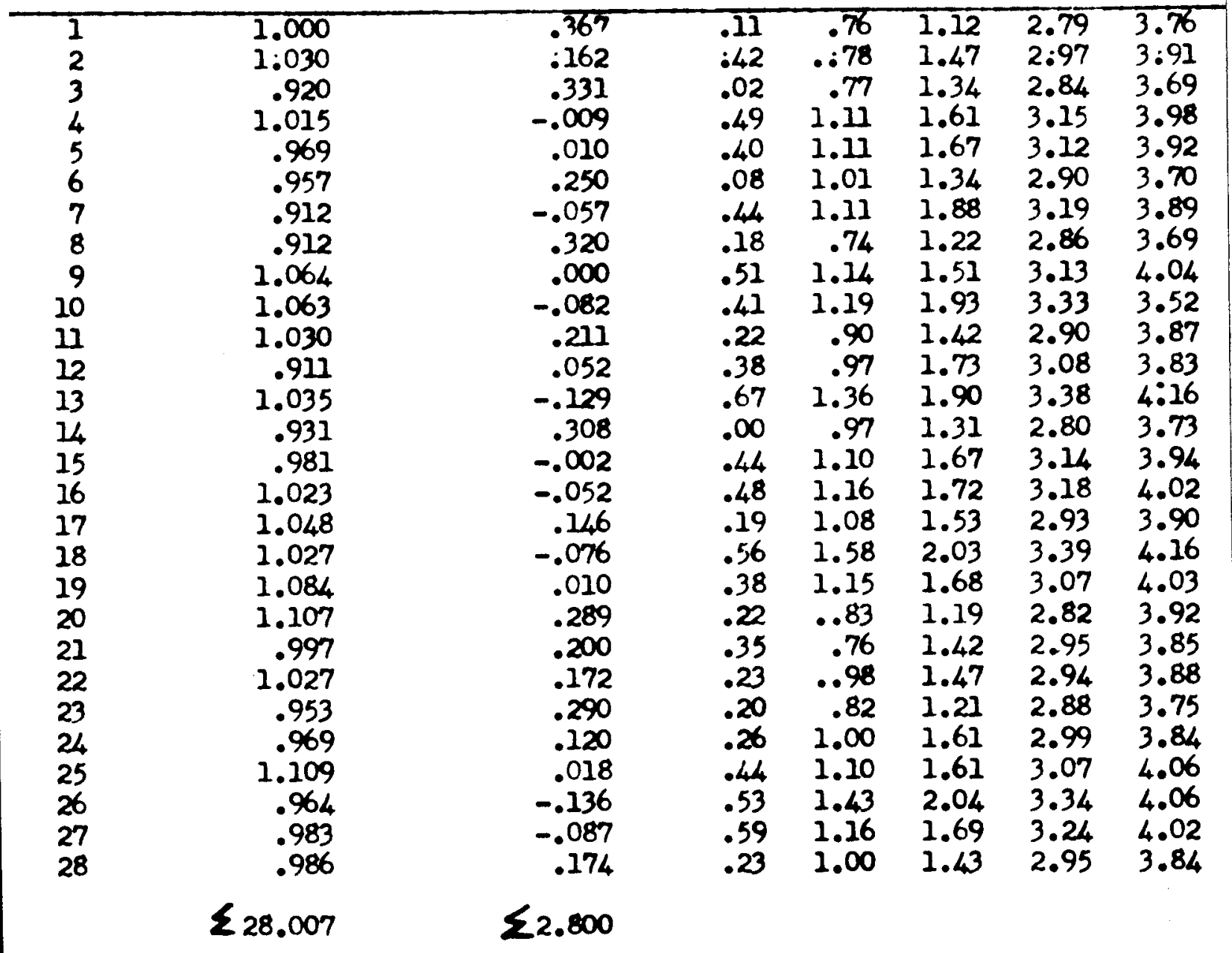


atatements in the soale $\left(\sum_{j} \sigma_{f}=28.007\right)$. Henoe, the definition of the unit of neasurement $\left(\sum_{j} \sigma_{j}\right) / \mathrm{n}-1$ as posited in the multiple category wethod was adhered to in soaling.

The normal deviate weights obtalned by the multiple category method (Table I) wer utllized in reseoring the attitude sonle protoools of 57 patients. The total soores were ocrrelated with the scores which had been oslculated on the basis of Integral wolghts assignad to each of the response oategorles. A coefflolent of .99 was obtained by wans of the Parson productwoment mothod of corribation. The relationah1p between the normal deviate and Integral weighting methods of sooming is graphleally 11lustrated in F1gure 2. The aubstant1al amount of agreement found between the two wothoda of sooring is in aceond with the finding of others who have imvestigated this yoblew (Likert a Murphy, 1937, Wobb \&obler, 1962). The Integral wolghting syotem of sooring was ut1lised in this study because of the comparat1vely gater ease it afforde. 


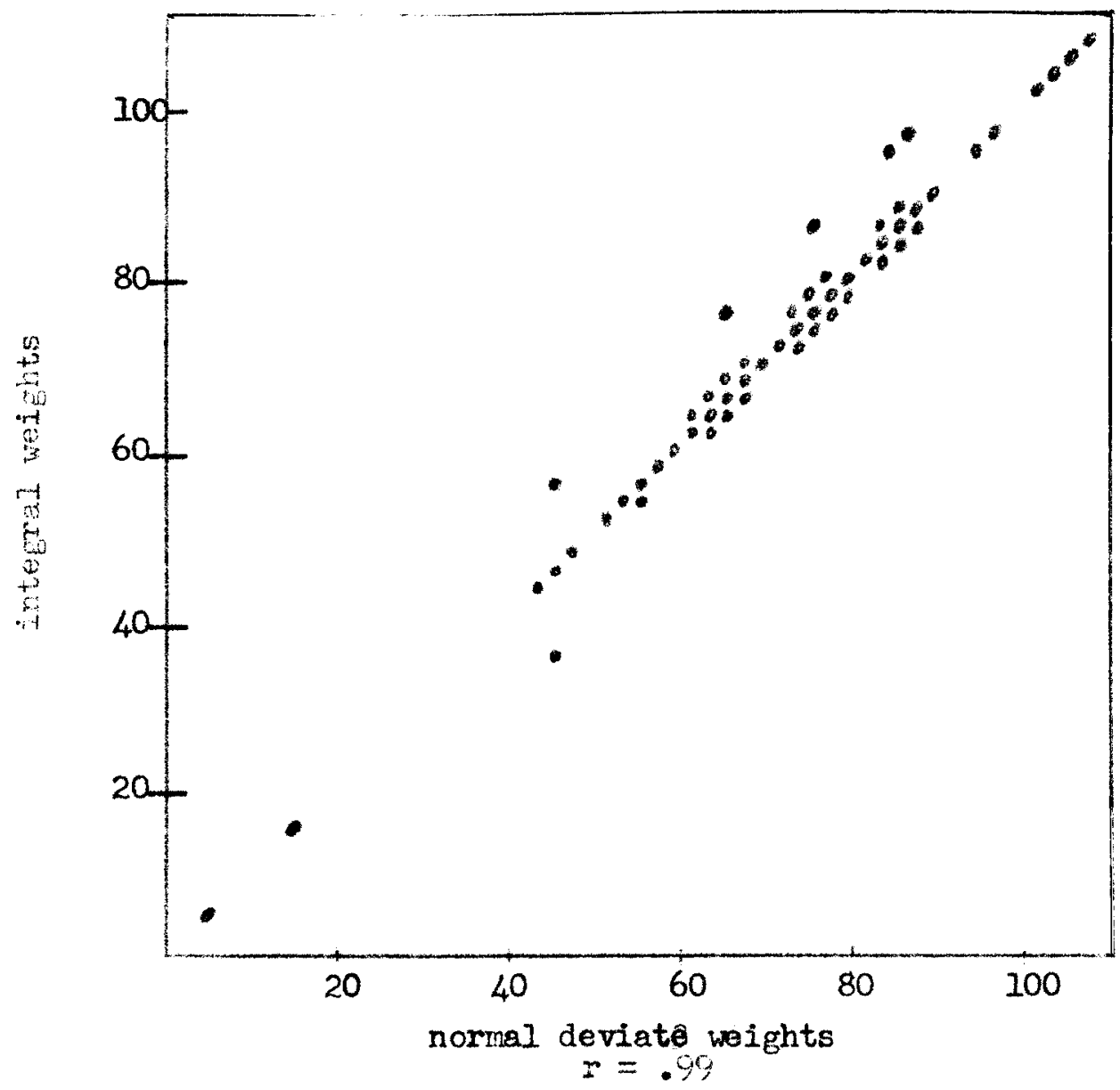

Fig. 2. Relationship Between Integral and Normal Deviate Weights Method of Scoring the Patients Opinion Poll 


\section{CRAPIBR IN}

\section{RELIABILITY AND VALIDITY STUDIES}

The foregoing ohapter dealt with the olintoal and emplrieal tochntquan utilized in developing the attitude sale. In view of the purposes for which the sonle was constructed, it is necessary to know how muoh confidence can be placed in the acouracy and stabillty of soores obtained on the soale. There Is alao a need to know the extent to whloh the scale assesses the rartable It was designod to measure. The present ohapter is oonoerned with the devisIng of procodures which will provide information about the rellability and validity of the scale.

There is scase degree of error in all measurement, and there are varlous ways of estimating the extent of this exrox. Bror, or accuraey, of measurenent may be eatimated by determining the extent to whloh repated masurements yleld sinflar resulta. The obtained rosulta are an indieation of the dependablilty or reliablitty of the measuring instrument.

The rellability of an attitude scalo can be estinated by correlating the odd and even atatements of the seale and applying the apropriate Speaman-Bromn formula. The reauting ooffielent of internal consiatency is an indiation of the extent to whioh the atstements are Interdependent and, as such, it serves a check on the assumption that the statement, were drawn from the same closs or univeres. Th1s estimate of rellability is partloularly moaningful in evaluating the adecquacy of attitude scalos bocause 
the attitude is defined by the correlatione among the individual respones. Covariation among responses is asaumed to be related to the variation of an underlying variable. If the statements are found to be highly intertependent, they are homogenoous and the att1tude sonlo is unidinensional. Suoh a I1nding would enable one to assue with some degree of certainty that alnilar soores rafloct inllar att1tudes about the prychologioal objoct. Homogenoity oan be thought of as an indieation of ralinbility, although, as Green (1954) has pointed out, it is possible for a seale to be highly rellable and not homogeneous. The coeffleient of internal oonsistenoy oan be deterained by either split-half or Ruder-Richardson type wethods (Amerioan Psyohologieal Assoolation, 1954).

Aleo, the rellability of an attitude scalo can bo eatimated sy odinistering the senle to the same group of subjects on two or more occesions with an apreopriate period of tine betweon teatings. A coefficient of otability 18 ealoulated by correlating the test and rotest scores. This eatiwate of rellabllity provides some information about the atabllity of the cocoses obtained on the ecale and is, therefore, relevant to the present study where there is interest in cotermining whothor anticlpatad changes in attitude following exponure to a partioulax treatment setting are due to the treatment oondition or the unstable nature of the soores. However, it has frequently boen found that the coefflelent of atabillty is inoreaned by momon and familiarity with a soale and decreased by extending the tine interval between testings (creen, 1954). Rogardlese of the length of the time Interval, there 16 alvays the posalbllity that sowe extranoous ovent will oceur and signifIcantly altex the attitudes of anbjecte toward the payohologloal object. 
The validity of an attitude scale oan be determined in eoveral ways. Ideally, it might involve oorrelating the elfolted verbal attitudes with some outalde orfterion, for exmple, with behavior ohookliat ratings baed on extensive observation of each individual etudied. In the event that the resulte of an attitude seale are to be ued as an Indioant of action, then, evidenoe of the latter kind of validity is required. If there is Interest only in determining the degree of relationship between one attitude and another, thon the vallalty of a seale might be estimated in terwa of 1ts reliabllity and homogenelty, that is, if the scale ware found to poseese these oharaeteribties, it would be measuring sons varioble. With respeot to the rwesent researoh, there is a generval laok of agreevent conoerming the nature and meaning of morale and no defintive orfteris for rating the morale of paychiatrio in patients have been deweloped. This atudy is an effort in that direotion. In view of the faot that the ecale developod in this otudy wight be aed ae an Indioant of future aotion, there was intereat in deterninIne the soale' validity by a wothod which would complewent and rollablilty and homogenolty data found.

The tern validity a weed in this researoh will rofor to the extent to which the eale asessed the variable It was dealgned to meanure. Bvidenoe of the vesie's valldity $\mathbf{w 1 1}$ be determined by comparing the coores of two group of Individuale who beoause of the differences in thair treatment sottings should obtain different scores on the scale.

Several hypotheaes 111 be proposed and tosted in an attempt to determing the attitude coale's reliablilty and validity. They will be presented in numerleal order, ant this yoten will be rotained in roporting the roults. 
The attitude seale w11l be raferred to as the "Futionte optuion Foll."

\section{Bel1abllity Expertmenta}

Aypothesis is If the Patients opinion foll is a reliable attitude sonle, there w11l be a high correlation betwon acores obtained by the amo Individual on two halves of the toet.

Method 1: A coeffiolent of internal consistenoy was obtained by adintnistering the Pationta Oplnion Poll to 57 paychiatric inpatients on the poyohiatry arvice of a large Veterans Administration hosptal looated in the Chicago aren. In attempt was made to administor the soale to all of the approximately 110 mationts on this servioe, but, for varlous roasons, this was not nossible. On the two open warda there ware 14 patients on passas and 13 patients who falled to show for the patient-counoll meeting at which the scale was admintstered. AII 24 of the patients attending the noeting comnleted the form. On the two locked wards, there were about 15 outright refusals to attompt the form and Iiv inoomploto reoord which aould not be moored. The remaindar of the pationta ware elther away from the ward, unable, or unwlling to cooperate. It should be noted that the hospltal in which these date were methered is not the same as the one in which the preliminary fom of the senle was developed. Each of the 57 rocords obtained was divided Into two halves, one-half oonsisting of the odd-number atatements and the other of the oven-numbered statomsnta. Bach of the halves was scored acoordIng to the provlousy outlined systom. The obtalnod acores were arranged In frecuenoy distributions and correlated by the Pbarson moductmonent nothod (MoNemar, 1955, n. 120). The Spenmen-ibrown formula (Carrett, 1953, p. 342) for estimating rellabllity from two comparable halves of a test was 
aprlied to the resulta.

Tyothests 2, If the Patients cpinion Poll is a roliable scalo, there W11 be a high oorselation batwoon scores obtninod the sane Individual on two saparate ocosions, the meind of tius batwean adminfotratinns balne two rooks.

Fethod 2, A coeffiolant of stabilty was obtainod by aninfsterine the Patients Opinton Fol1 to 62 pyohtatrlo ingutients on two soparate

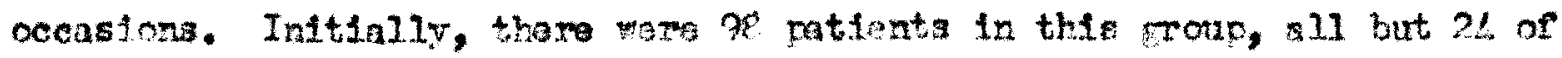
whom wast as igned to thro opan waris on the newropsychtatrie-tubarculosis (NP-PB) serrice of the Domney V. A. Hospital. Twenty-eight of the NF-TB patiente did not comlote the seale in spte of individul recuests and enconrapamont, mekting l.t imnossibl to computo scoros for thatr reocrds. Three other retients in the orifinal group "aesed with all or most of the statorents; because of obvione response inconsistencios, these reoonds pere not Inoluded in the stidy. It should ho noted that in the exporimont

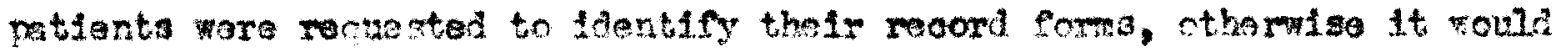
have baen inposaltle to natoh their renords followiaf the scoond edmintstration of the scale. Thay mo not inermed that there would be a cocord adainietration of the ecels, only that the In sefstance wos noeded in oriar to determine the value of rresent tregtment methods in the hospltal. Four other petients were not asilable at the tine of the second adninistration of the seale, ant one rafused to complote it a seond tino. Hence, slightiy more then one-thin of the cricinal sample was lost in the coures of this exporinent. The tro set of obtelned soores were correlated by the foarson productmoment method of correlation for moured data. 


\section{Validity Experdment}

Wypothesis 3: If the Matianta Opinion Poll is a valld mensure of patients' attstudes toward their wards, then the mean seore of a rroup of petients who have been exposed to a therapeutic community type of sard situation should be stpnifleantly higher than the mean score of the same groun beforo exposure to this form of treatment.

Method 3t It is as suned in the above hypothesis that the experfences which these natiente undereo in the experinental situation will be favorable and will faoliftate changer in attitide in that direction.

The hypothesis was tested, firat, by admintstaring the attitude soalo to every avaliable thite male who was admitted to the psyohiatrie cervioe of The Downey v. A. Hospital during the reriod Maroh through Septerber, 1962. The seales were admintatered on the wards to which the patients were assigned, and no montion was made of any posaible tranafer to another ward. Buphasis was placed on the usefulness of knowing what patients thought about conditions on the ward. Also, these netients had been living on their wards for a period of time, two to three weeks, whioh was affiofently long to famillarize them with the situation. Within a weok these patients rooolved a mineographed invitation to visit the Motivation Unit, that is, the experimental ward. Those patients who acoepted and who wore allowed to aceept the invitation were given a tour of the unft and an explanation of its program and poals. Then, they were interviewed by the Unit's "ataff" which consiats of a payohologist, a paychnlopy traineo, a olerk-stonographer, and one or more nursing asaistant (aldes). If a patient indieated that he was not interested in transferring to the unit, he returned to and remained in treatment on his original ward. If 
a patient indioated interest in tranaferring, but the staff considered him unsultable for the program of fered on the untt, he was dropped from considoration. Those ratients who expressed interest in transforring to the unit and who were considered acceptable by the staff ware informed that, if it were possible, they nould be transferred to the Motivation Unit. Whenever there was an equal number of aonoptable candidates for transfer, they wore randonly assigned to experimontal and control groups. Those patiente who were assigned to the control group remained in treatment on the wards to which they were originally assigned; there were 20 petients in this group. These natiente who were assignad to the experinental groun were transferred to the Motivation inft; this group consiated of 20 ratients. The valldity hypothesis was tested by ro-aimintstering the attitude acale to the patients In both grouns. It was antiolpated that the effect of exposure to the treatwont oondition would be experienced within one nonth's time. Henoe, a period of aproxinately four weeks was allowed to olape between administrations of the scale, The pro- and post-test moans were calculated for each group. The statistical signiflanoe of alfferance betweon the pre- ant post-treatment means of each group was determinod by the following formula

$$
t=\frac{\left(\bar{D}-\bar{D}_{D}\right)}{\sqrt{\frac{N \sum D^{2}-\left(\sum D\right)^{2}}{N^{2}(N-1)}}}
$$

where $\bar{p}=$ the mean of the differances botween pre- and post-trestment scores $\bar{E}_{n}=$ the mean of the pomalation of differonces $\mathrm{N}=$ the total number of patiente in the group $\Sigma D=$ the oum of the differonoes between reo- and nost-traatment soores 
A t test of differences between means of two correlated samples was ueed because in this exporinent the ane individuals were moasured before and after treatment (Tate, $1955 \mathrm{p}, 466$ ). This formula assumes only that the anple of differences is drawn randomily from a normal population of differences. The total change in the control group was aubtracted from the total ohange in the experimental group, resulting in a not change the signifleanoe of whioh was determined by mane of a "th" teat of differenoes botween meane of two indepondent, amples (Tate, 2955, p. 463). The following forwula was used:

$$
t=\frac{\bar{x}_{1}-\bar{x}_{2}}{\sqrt{\frac{\left(\sum x^{2}+\sum x_{2}^{2}\right)\left(\frac{1}{N_{1}}+\sum_{N_{2}}\right)}{N_{1}+N_{2}-2}}}
$$

Where $\bar{X}_{1}=$ the mean soors of the experimental group on the attitude soale following treatment $\bar{z}_{2}=$ the wean score of the control group on the attitude ecale
following no treatment

$N_{1}$ : the number of pationts in the exporimentel group

$N_{2}=$ the number of patients in the control group

$$
\begin{aligned}
& \sum x_{1}^{2}=\frac{1}{w_{1}}\left[n_{1} \sum x^{2}-(\Sigma x)^{2}\right] . \\
& \sum x^{2}=\frac{1}{n_{2}}\left[n_{2} \Sigma x^{2}-(\Sigma x)^{2}\right] .
\end{aligned}
$$

Thio formula was ueed because pationts wore assigned to the two groupe in a randon manner. This formula as numes that the eampled populations are alike In variability $\left(\hat{\sigma}_{X}=\hat{\sigma}\right)$ because algatfloant value of "th could arise in 
sampling frow populations havlng equal means but different atandard doviatlone. Hence, the elgnifleance of the differenoe between the independent sample vartanoes was teated by the varianoe rat1o $F$ (Tate, 1955, p. 493). The obtained value $(F=.597)$ was within the region of aocoptance at the .05 level of aig ntfloanoe. The assumption that the sampled populations have equal varianoea was, therefore, tenable and use of tho above "t" test was appropriato. This design is based on the uggestions of MoNenar (1946) and Tate (1955). In both teste of efgnifloance, the mull hypotheals w11l be aooepted or rejeoted at the .05 Iovel of oonfldence.

Deacustition of the Bonatmant Sutting ${ }^{3}$

The Downy (Veteran Aduiniatration Hoapital) Motivation Unit is a 50 bed peyohiatrie werd lovated in one wing of a large butlding whioh otherwise houses geriatrie patients with neuropoyohiatrio conditions. It is somevhat reavod from the other peyohiatwio waxds of tho hospltal, and it Alffers from other wards in torws of Its organization and phllosophy of treate Dent. These difforenoes are eapecially apparent in sevoral areas.

\section{Adminintrentire Rosmoniblutws Staff wombere and wo in treatmont,} who are not referred to as patients, on the Motivation init share the reaponafbillties and benafits of the unit by jolnt partiolpation in discuesions and polley making sessions. There are no unilateral decisions, the wen in treatment having an equal volos in deolelons affecting the Unit. On other wards of the hospltel the medioal staff has prinary responsibllity for pationta; It direct the operation of the ward. The ward physician oaptains the toam; his ordere and adniniotrative deolstons are oommunioated to and carrled out by the nureing otaff. 
2. Commintentions The mon in treatmont on the Motivation Onit are onoouraged to oomunioate openiy thelr 1deas, questions, interests, feelinge eto.f poirlledged ocmmunication ocours only when it is therapeutioally noe-

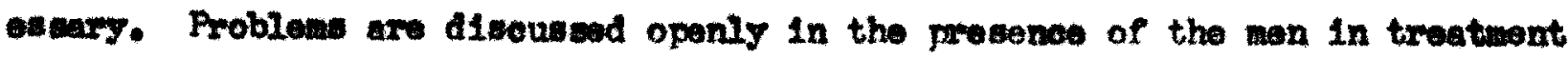
and starf mombers then, declatons are made demoeratically. Clinical records are kept but de-emphasised. In contrast, on other warda the physielan diagnoeag and prosertbes treatment for the patient. The dootor ocmunteates thl inform mation, elther vorbally or in writton form, to those staff nembers whose profoselonal training ordinarily qualiftes them to underatand it and to was it in their dealings with the pationt. The nurwos, eoclal workers, poyohologiets, opocial theraptets, and other members of the staff use this information al a banis or fram of roference in their aprroach to and treatment of the patient. In turn, they relate to the dootor in ofther written or apoken form their F1ndings, obeervatione, results, oto./ these data are utilized by tho dootor In evaluating the pationt and in dooldine whother to continus, revioe, or dicoontime the present oourse of treatment for a given patient. The physiofin Informs the patient of any ohange in treatment mooedure or he has one of the

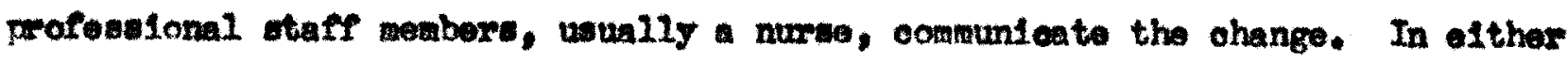
case, the physiofan uevally deoldes to what extent the patient shall be informed regarding the reasone for suoh a ohange. In turn, the pattent my conmuntoate Information to the physiolan whioh is or is not relayed to the other members of the team. Non-profossional employees, nursing assiutants, and houeveoping pooplo, ordinarily are not invitod to partiolpate in team or ward meetings.

Adalntatrat1we problem on other wards are brought up and disousad by 
the professionsl staff members, usuily in the mivacy of an office or nonference room. The physiatan reviews these problems in the 1 toht of his reapongibilities to the patlents and to the arluinistration of the rard. Te and his otafi discuas and dectie tho manner in whioh tholr dectalons are to be carrisd out. Their discussion remains confidential.

3. Stafe Status: Differonces in status anong staf nembers and men in treatment on the Motivation "int are miniel zed in order to dininish the number of autoratic actions taken. Any actiona taken on the unit may be questlened by anyone. In contrast, difforences in status among atafe membera and between otaff mombers and pationts are readily apparent on other wards. Fatients and visitors have little difficulty ldentffying staff nombars, distingushing one profesatonal from another on the basts of alther his untform, showlder onblem, key chain, Identifloation badge, rofoselonal gadpats, oto. These moreasionals uswaly are avallable for appolntment in their offices whore other paraohernalia, certifloates, diflomas, t1tied desk Instenia, oto, furthor olarify their funotions.

4. Rales: Breryone on the Motivation unit is encomraged to be himself, to abandon unfforms or other distinotive insignia, and to rofrain from distinetive actions essoclated with particular roles. Hence, role-blurring and cooperation charactorize the unit. imphasis is vlneed on acomnlishing what nead to be cone together rather than on who should do it. Whon foint assoussion leads to decisions, oach staff menbre is oncouraged to aot autonomousiy in oarrying out the onntemplated aotions.

In contrast, on most wards the roles of the various staff members are clearly defined, each momber belng responsible for the earrying out of the 
declstong and directions of the myricien and his toam. The staff members soe to 1 that the natients oomply with there directinns. In addition, patients are orlanted as to treatwent prooodure and hospltal rengrams by means of lecturea, intarviows, mues, and regulations.

5. Came bv the Stafe: Man in troatment on the lotivation linit are glven every opportunity porsible for carrying out of thetr parsonnal affalrs. They are afforded with a degree of fraedom approahing 11 fo outside of the hospltal in order to develop thalr totentialities for self-reltanoo.

On other wands of the hosptal the medieel and other professional atafe are responsible for the care of the patient. The person most intimately involved is the nursing assistant who is on the ward with the matient, he is responstule for the safety of the patient and he ses to it that the patient follows the physinian's and nurses" orders.

6. Treatmant Brocess: In geners1, overyone on the Motivation Untt is "In trastment," that 1a, Involved in tho process of treatnent. Staff members who aky be enoountersing roblams in dajly ifvine ere afforled opportunities to relnte their diffenitiec, and they can expect to recelve the coneern and asafetance of others on the unit. This mutuel concern for the well-being of one ancther and whe Froup is an essential characteriatio of the treatment rrocess on the inotivation Inst.

The staff nembars on other wards tymically nake ovary effort to provide for the well-bolng of the netsent in orier to help him feel securo, safo, onocuraged, nni active; omphas is nlaced upon utilizing the avallable plant resources and professionaliy qualified staff members. Linitationa and rreeautions, if any, are clearly indicated by the pationt's physician in the 
clinical records and followed by the nurses and nursing assistante in deterrining what the patfent an and oan not do. Patients are informed of the IInfts of what aotivities they may undertake elther by way of direct conmunieations, the passes they are granted, the posted rules and regulations, or by all throe means. They may or may not be adviaed of the reasons underIying declatons regarding the limits of their aetivities. They are also Informed of what they may expeot of parious staff members. These rrocedures serve to establish and maintain clearly the limits of the prescribed troatment program wthin which the patients and staff members funotion. 
CHAPTER V

\section{ANALISIS OF RESULTS}

The resulte of the rellablilty and validity experients will be presenta In the eame numerioal order as the related hypothoses were in the preceding chapter.

\section{Baliabluty of the Patienta Oninton Boll}

\section{Internal Consiatenoy.}

Hypothese It A coeffielent of internal consiatenoy was obtalned by correlating the soores of 57 payohiatrie inpatients on eplit-halves of the att1tude soale. One set of scores was based on the reaponses of these patiente to the oven numbered etatements of the attitude soale, the other on their responses to the odd nubered otatements. A ocefficlent of . 91 (P.<.001) wal obtained by means of the Pearson produetmonent methed of oorrelation. The distribution of the soores on which this ocefflolent 1. based ean be sen in Figure 4. Applioation of the Spearman-Brown formula to this ooefflolent rated the correlation to $.95\left(p_{0}<.001\right)$. This coeffiolent ocmpares veny favorably with others roported in the literature for aruated-rating scales. Edwarts (1957) presents a number of correoter rallability noeffictents for aunated-rating scales, simple inspection of these rosults reveals that they range from the high $60^{\prime} \mathrm{s}$ to the $10 \mathrm{~m} 90^{\prime} \mathrm{s}$. Henoe, the coefflolent of internal consistenoy obtained in the present otudy is such that the statemente appear to be highly interdependent and howogenoous. Further, it oan be assumed 
With oonsiderable confidence that the ocale is untdimonsional and rellable. Ono praotioal implieation of this finding is that patients who earn similax soores can be assumed to have about the same attitude toward their wards.

\section{Stability.}

Aypothenis 21 A cooffiolent of stability was obtained by adninistering the attitude sosle to 62 peyohiatrio inpatients on two warato occastons and oorrelating the scoros. There was an Interval of approxdately three weeks between administrations of the soale. A coerfiolent of .61 $\left(p_{0}<.001\right)$ was obtained by means of the Peareon produot-moment mothod of correlation. The dietribution of the woores on which this voofficient is baced can be meen In F1gure 5. Th1s ooeffieient auggests that less oonfidenoe can be placed in the stabllity of soores obtalnod on the sealo than had beon hoped for. On the other hand, it should be noted that both Hall (1934) and Sletto (1937) obtained lower rallability ocerflelente on their morale soales than on any of the oeveral other seales they developed. Hall reported ooofflolente from .69 to .84 for his morale soale of oniy flve statements, and Sletto's morale soale of 22 otatements gave aplit-half and test-retent (two month time interval with 50 subjeote) ocoffiolents of .72 and .61, reapeotive1y. Further, It should be reoslled that the present scele was developed rriwarlly for the purpose of distingulshing rellably between the moans of two relatively all group and not to differentiate among Individuals in a group. In the latter ease, a rellablitty coeffielent of .90 or more would have been noosssary; for the purposes of the present study, a coeffiolent of more than .50 should be ouffielont (Garrott, 1953, p. 338). Finally, it is ontively I1kely that a higher coefflelent of atability would have been obtained if 


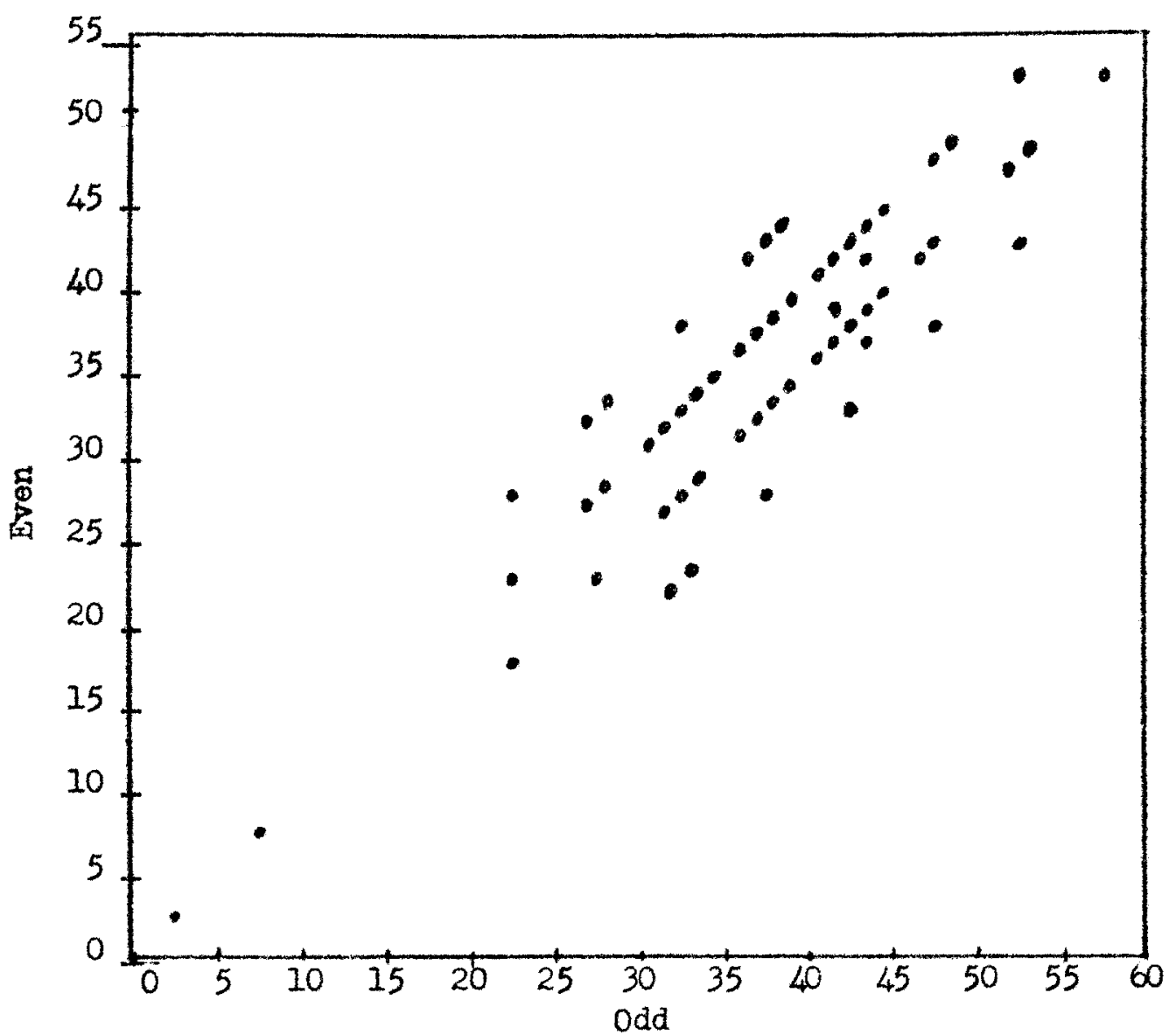

Fig. 4. Coefficient of Internal Consistency for Patients Opinion Poll. $\mathrm{r}=.95$ 
68

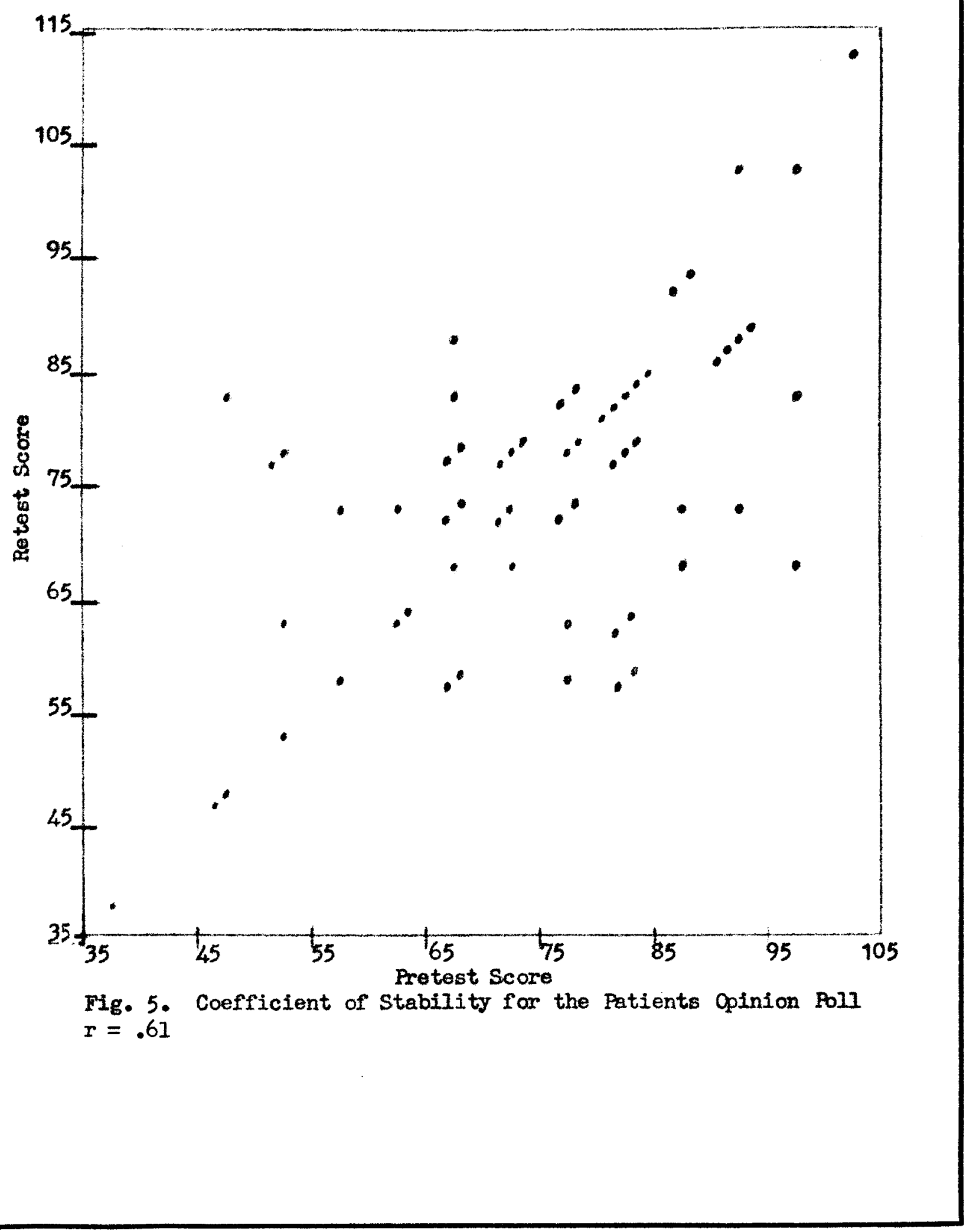


greater caution had been ued in seleoting pationts for this experinent. As a group, the NP-TB patients showed less interest in the attitude soale than patiente on peychiatrio wards, and an Inspeotion of the reocrd blanje revealed that nearly all of the individuals who produoed the most variable socres cano from APMB warde. This finding wight be aecounted for, in part, by the disolowre that during the time interval between teatings thare were so many peraonal thefte on one bullding that the medical ohlef of the cervice threatenad to "get tough" with the pationts there uniesa it ceased. In addition, the witer felt that a number of these patients were not eapable of excroluing the ecourate introspective peroeption neesesary for completing an attitule soule.

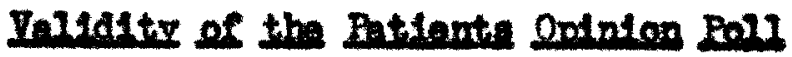

Hypotheeis 31 The validity of the attitude coale was estinated by comparing the soores of two groupe of patiente who wore preatued to have different attitudes towand thels waxde because of the differenees in the organization of and treataont on thoir waxds. An exporinental group of patiente was exposed to a therapeutio commity type of peychiatrie treatuent situation, and a oontrol group of patients remalnod in oomentional treatment on other wards of the hospltal. Both groupe were pro- and post-tested, the interval between testing beling approxdmately one month. The reaulte, provented in Table 2, indloate that the experimental group ohanged on the average of eixteen and on melf polnte in the direotion of favombleness, while the control group changed on the average of only two pointa in the same direotion. Both the gross and net ohanges wore statiotioally signifleant $\left(p_{0}<.025\right)$. It ohould be noted that the allght ohange in attitude on the part of the control group 


\section{Table 2}

Change In Mean Scome on the Patients Opinion Poll a a Rosult of Four Week's Ixposure to the Experimental Treatment Setting

\begin{tabular}{|c|c|c|c|c|c|c|}
\hline \multirow[b]{2}{*}{ Group } & \multirow[b]{2}{*}{$\mathbf{N}$} & \multicolumn{2}{|c|}{ Mann Sanera } & \multicolumn{2}{|c|}{ Diteremen } & \multirow[b]{2}{*}{$\mathbf{p}$} \\
\hline & & Pretast & Retest & Grose & Net & \\
\hline Bxpezinental & 20 & 69.50 & 86,00 & 16.50 & &. .005 \\
\hline Control & 20 & 73.25 & 74.95 & 1.70 & & \\
\hline Total & 40 & & & & 14.80 & .025 \\
\hline
\end{tabular}

atens prinarily from the ohange in attitude on the part of one pat1ent who was tranufermed from looked to an oron ward during the tins intorval between teatings. He rated the open ward 39 points higher than the looked one. In goneral, the results of the validity experiment are onoouraging. They indioate that, on the average, patiente who are expowed to a therepeutio oommunty type of poyohiatrie treatment situation experienoe favorable ohange in attitude toward the ward, while their peers in oonventional treatment are remalning rathar oonotant in their attitudes toward thair wards.

\section{Desmenton}

The experimental results presented above indicate that the Patienta Opinton Foll is a rellable and vilid wothodolog for aseseing the attitudes of poyohiatrio inpatiente toward thoir hospital warde. There appears to bo scme ned for additional evidenoe regarding the dependabllity of soores carned on the sole if it is to be ueod in Investigationswhero ther is intereat in differentiating among patienta in a group. The writer plans to gather this 
ovidenoe by developing a parallel form of the seale. In view of the fact that all 82 otatoments of the prelininaxy attitude sole were found to difforentiate -ignifleantly between the average responses of the high and 20 oriterion groupw. It should be poselble to oonotruet a parallel form with 28 of the 54 romining statoments. A eosflelent of equivilenoe could be determined by adinintering oach of the two foras to auple of pationti on two different cocalion and oorrelating the coores. This coefflelent would provide an eetimate of the extent to which the attitude scale is specieso to the paxtiowlar etatemonts utflized, and it would not be as vulnerable to the effects of

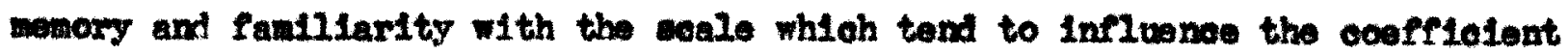
of etability. Further, a parallel form night help to overoome the resiatanee which nuber of patients showed to taking the save form a sooond tine. 1100, there is noed for greater oridenes conoerning the attitude acale' validity. This might be gathered by enlarging the oontrol and experinental group and retaining the test-rotent proesdures enployed in this atudy. Bnlarging the groupe, however, would require a considerable amount of time to obtain a saell number of patlente for study. It was nocesaary to pro-toet 136 patiente over a seven wonth's peried of tim in order to obtain the 40 oubjecte reported on. A largo mubar of patiente did not aocept or were not allomed to aoopt the initial invitation to visit the experimental ward. Henee, It would appear to be nocseary to develop another mothod for aheoking the validity of the attitude soale. The mont feasible mothod might involve the developing of a rating soalo or bohavior oheokliot whioh would onable an Irvestigator to reoond his observations of a given pationt's bahavior and verbalinations which relate to feeling about the ward aftuatlon, Attitude 
soale scores oould be correlated with roores basad on the rating soale, the rating weale serving as an external oriterion of workle in the sense that the tera 18 used in this study.

Also, correlations between the Patients Opinton Poll and other wore general measures of morale (KaIl, 1934; Sletto, 1937; Remaers, 1954) might be obtained in oxder to deterwine the degrea of relationship between thece measures. Such result would provide information about the variable of moralo and the Interralationshlp of the several "aorales" to whtoh MoNemar (1946) refors.

At prosent, the writer plans to oheck the validity of the attitude seale by periodiea11y aduinletering it to random samples of patiente on several wards of a large $\nabla$. A. hospltal. Mean scores will be obtained for each of these wards and they will be correlated with woh data so the average number of elopenents, Irragular discharges, ospeolally those gramted "agalnst medieal adv100," and disojplinary actions for a set period of time on these wards. These kinds of data veem to be especially relevant to the morale lovel of a given ward. For example, the writer has observed that the largest share of "agalngt medieal advioe" dieoharges from the hospltal seen to be ocourring on two wards of one butlding. Thie kind of disoharge genorally oocurs when there is genuine dissatisfaction on the part of the patient; souch, it is an Indieation of unfavorable feeling toward the ward. 


\section{CRAPTER VI}

\section{SUMARY AND CONCLUSTOAS}

Bridenoe eubatantlating the influance of social forees upon the clinioal course and reovery of paychiatrio patienta and parallel developents in soolom oultural theory have been inatrumental in precloltating the aramatio ahanges whloh are oocuring in mental hospltals. The already effocted and recently Froposed Innovations in the organizational atructure and treatment programs of mang wental houpitals, as vell as in the training of psychlatrlo porsonnel are representative of the current emphasis being placed upon the utillation of sociompoychologleal processes in the treatment of individuals hospitalized for pryohiatric oondition. There is widespread bellef that these dieorders are oawed by adverse enviromental airounstances and that they oan be moot offectively ohanpod by the exposing of Individuals a affeoted to an optimal soolal ollnate. In keeping with tho goel of social rooovery, etress is plaoed upon bolning individuals to sotablish and maintain mutually benofiolal interm personal relationshlpe.

An attempt has bsen made to provide a roview of some of the publleatione whloh are baslo or related to the present study. Several aneodotal reports (Klewer, 1951, HLhas 1s, 19473 Todd \& Fitkower, 1948) streasing the relationahip of morale to therapeutio outcoms in the poyohiatrio hospltal and ane deseriptive socount of the breskiown of morale in a mental hospital (Stanton 8. Sohwarts, 1954) wero citod and ovaluated. It was noted that there was a 
puolty of studies dealing with worale in this esting, the wejority of suoh studies belng fooused on the morale of industrial workers anc smad forces personnel. The conoentusl dlasgreement surrounding tho concept of morris and the attemnta at olarification by severai partios (Slotio, 1937) intional Rosearch Council, 1940; Child, 1941; Gladston at al., 1958) as woll as MoNomar ty (1946) empirially sound proposal for bringling order Into this araa were reviewed. In keoping with the first two aspect of Molvens's plan, favorablonoss of regard for the ward was postulated as being one oomponent af morale in the payohiatrio hoopital in wuch the samo way that Campoll (1955) postulate? "happiness" as belng an indioant of the moraie of abmarine orewa. Further, anidimensional attituie sosle was proposed os the methodology for assessing this variable.

The conoept of attitude wat discussed, and a brief resume of tis origina was resented. It was noted that there is an implieả or explicit ouphasls upon readiness to respond in the repertoire of ourrent knorioan tefinitions of attitude. The medoninant tondenoy to regard attitude as a hypotiotical or latent variable and to define it in terms of the corrolations which extat among responess to a seoffled set of stimuli, or social objeots, was mentioned by way of indioating the rationalo for measuritag attitides. Sone of the aseup tlons underlying the development of attitude scales and various nethods anployed in construoting then were discussed. Various roasons for solecting the method of summated rating as a tochnique for devaloping tha sttitute scelo mero presented.

Several studies of the attitudes of peychiatrio pationts wore evaluated oritically. The investigations by Hatoh (1948) and Caudill (1958) wore 
fosued on attitudes toward various aspots of pertioular mental hospltale; In each oase the data were obtainad by Interview wothode the objectivenesa and completenose of whioh 1s questionable. Further, their resulte are pecullar to the eotting in which they wore gathered and diffieult to quantify for parposes of omparison. Mont of the othar aturies of patients' attitudes (Souslem, 1955, Klopfor at al., 1956; Rernikort et 1., 1959, brady at al.. 1959; Wolfenobergor, 1958, Inre and Wolf, 1962) are focuaed on the attitudea of payohlatrio patiente toward "montal hosptala" and ut1line as their wothodologg for abeveng these attitudes the seale developed by Somalen (1955). Although oredit was given to souvlen for suggesting that an attitude soale auch as hore might bo used in assossing patient morale, soveral oritiolowe were leveled agalnet her wosle. Firet, now of her statements deal with ang kind of inter-

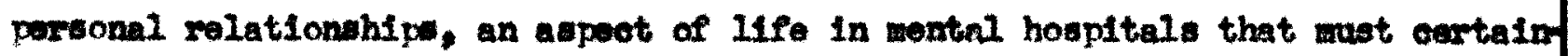
Iy constitute on of the suboleasen of atatements within the univeree, os class, of all poselble otatemente that can be made about a mental hospltal. Thic onisalon, plus the laok of contradiotory evidenos, suggeste that Souvlen rolied upon her intultion in writing and selooting atatewente for her soale, a questionable and unreliablo prooedure. Mleo, the fallime of Souvlew's soale to distinguish groupa whioh on an a relont bats were expeoted to reveal differences in attitude and the pausty of oroesmalidational findinge raised doubts reganding the usefulness of the souelen soale.

In sumwary, a review of the Ilterature dealing with the noralo of poyohlatrie inpatienta Indicated the noed for a more syotematio means of irreatigating this important varlable. The literature dealing with attitudes and tholr moasuremont revealed aeveral ways of carying out this investigation. 
And provlous studies of patlent attltudes elther were focused on different paychological objeots of enployed methods and procedures whioh have sentou shortocmings. The ned for a rellable and ralld wean of assessing the attitudes of peychiatrie patiente toward thoir 1mediate treatment setting, thair warde, was Indioated.

The present study deals with the dovolopwent and otandardization of a methodology for assousing the attitudes of paychistrio pationte toward their hospltal varde. Provious atudies of the attitudes of poychiatrio patiente have been fooused on different features of the hospltal setting or have ut111sed mothods of data oollootion whioh do not lend themeelven to quant1fleation for purposes of oomparison. In this atudy attention was fooused on the ward oituation and there was interest in determining whether ohanges in attitude toward the ward are ansoolated with difrerenoes in treatwent prooedure on the wayd. Henoe, It was noovesary to develop a reliable and ralid wean: of meanuring ohange in attitude.

A melininary form of the att1tude cole was conatruoted with atatements obtained from fou major sourbes. The litexature dealing with mental hoepltale Inoluilng the scoounte of forwor patients, was aurveyed. On humired-twalve patlente on various wards of a large peyohlatrio hoapltal were adminietered a mimographed sertes of ten Inoomplete cantences dealing with varlous ward toplce. Taperreoorded, open-end type Interviews with patients wero used ae another source for statemants. Pinally, the transoribed winutes of a large number of patient-oounc1l meetinge wore searohed for onntent perteining to ward situation which on noerned pat1ents. The obtained stateante were cosplled and olaselfled. One humdred and forty-two atatements, covering one 
or wore anpots of all the major areas wentionod in the data, were selocted and aubaitted to aix pryohologiste for avaluation. 1 preliminary attitude oole oonsiotine of 82 atatemento resulted frow this analyois.

The responses of 200 patients on the prelininary form of the attitude soale were anored acooxding to the wethod of sumated ratings. The soores were arranged in a frequenoy distribution, and orlterion groupe oonaleting of the upper and lowar 27 percent were elected. The protosole of these high and low soorers were ut1lized in coloulating t-values for the 82 otatements. A1I of the statements were found to be expable of ellelting alear differonoes of attitude. Twenty-1ght of the 82 statemate were selected for the final form of the attitude acale. They wero coaled aocording to the waltiple oategory method and found to be somewhat unevenly distributed through the unfavorable-favorable continuxin, there belng about twise as mang statemente with positive soale valuea as megative soale values. The multiple categry method was used in oaloulating normal deviate wolghts for the flvo sooring categories of each atatement. Fifty-seren attitude ocale protocols were remsocred on the basis of those weighte and oorrelated with soores basod on Integral welghts. The resulting coeffiolent $(.99)$ refleoted a high degroe of ocrrespondenoe betwoen scores based on the two syotems and fuatifles retaining the implex method of integral weighting for sooring the seale.

The rollability of the attitude acale was estinated in two waye. A eplit-half rellablifty ooefflalent of .95 was obtalmad by corralating the soorea of 57 peychiatric pationts on the even numbered statements with theif seores on the odd statements and by applying the appropriate Speaxman-Brom osreotion formula. A testmptest rollablilty ooefflolent of .61 was obtalnad 
by correlating the soores of 62 paychiatrite patianta on two different cocalons, the Intervening cerlod being silghtly more than two wokk. Both of thase com efflotents aro algnifloant beyont the .001 level.

Bridence of the attitude sosle's validity was estimated by comparing the

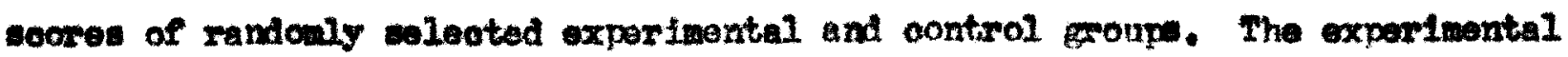
group was expoed to a therreutio ocemuntty type of peyrohiatrio treatment for approximately one wonth, whils patfents in the control group renained on the hospital wards to which they had been assigned. It was hypotherized that the mean seore of the experinental group on the attitude soale would be elgnifloantly higher after this treatment than before. The experinental and oontrol groupe pere- and post-tested. Results indioated that the patiente In the experimental group experienced a ignteloant ohange in attitude ( $\left.p_{0}<005\right)$ producing poot-test soores whioh on the avarage were nore than veventeen points higher than their pre-test scores, while the patlents in the control group romained relatively contant in their attitudes towerd thair wards, earning post test scores which on the average were less than two pointa higher than thelr pre-test soorew. Also, the net change besed on the difference betwoen the post-test means of the two groupe was highly algnifleant $\left(p_{0}<.025\right)$.

On the basis of the experinental results, It was coneluded that the attitude woale is a rollablo and valid nothodology for asseseing the attitudes of payohiatrie patients toward their wards. Tho ase and speed with whioh the walo oan be adminietered will nake it poselble to study and compare larger groupe of patients than has been posaible with the 1nterview methode used in previous studies of patient attitudes,

If one accepts the widely held conviotion that disondered poyohologiocl 
79

functioning is largely a function of the social setting in which it occurs, It follow that methodologies mut be developed to study the nature of molal climates. The rosie developed in this study was used in evaluating a there-

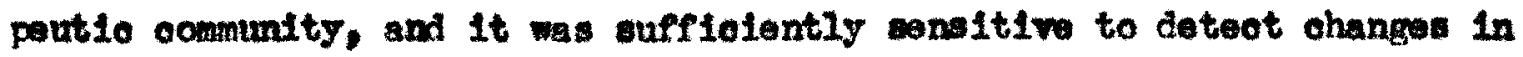
attitude which occur as a result of exposure to this kind of social olingte. Other bes to which the cole can be put were proposed and discussed. 


\section{BIBLIOCRA PFI}

Alohhown, A. Marmand youth. New Yorka V1k1nB, 1935.

Allpent, $G$. The nature of personallty: seleeted paperv.

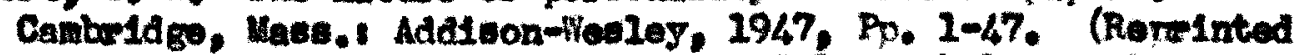

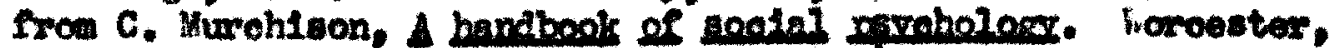

Hass. Clark UnIver. Fress, 1935, Ch. 17.)

Alvares,. C, Uinis that same back. Philedel phias Lipoineott, 1961.

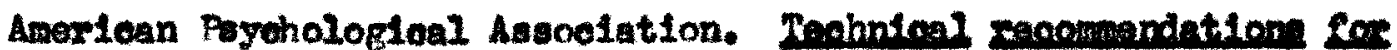

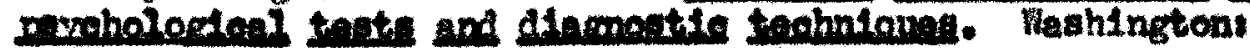
American Peyohological Asscelation, 1954.

Anomparis. The grand fury report on the wate hospltal. Publo (Coloredo) Chioftain, May, 1962.

Bechr, Melany $\mathrm{z}_{0}$, \& Renok, R. The derinition and nosourenent of empiogeo morale. Adintn. ant. arate, 1958, 3, 157-184.

Bales, R. R., \&later, P. E. Role differentiation in small deeision makding proupa. In T. Paraon R. F. Bales (Bds.), Fantly.

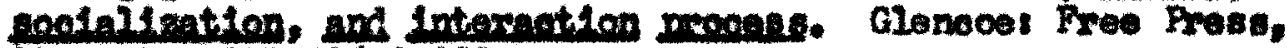
1955, Pp. 297-298 \& 302 .

Boory, C. N. A mind that Comd 1teale. Now Yorki Doubloday, 1953.

Bell, O. H. A mental hoopital with open doors. Int. I. Son. Brombito, 1955, 1, 42-48.

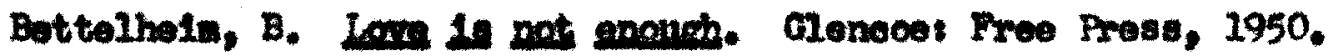

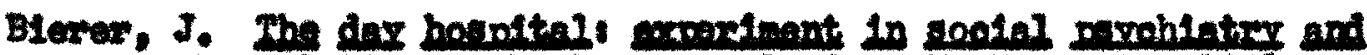

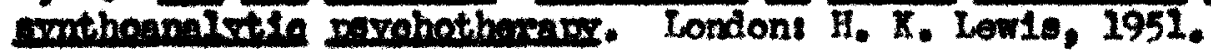

Blon, W. R. Bxporlenoes in groups, Hur. Belat., 1950, 3. 3-15.

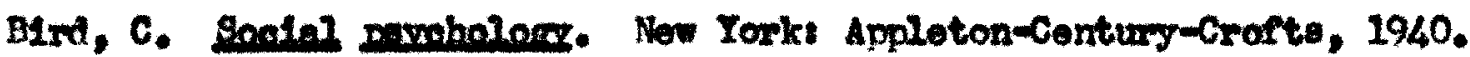

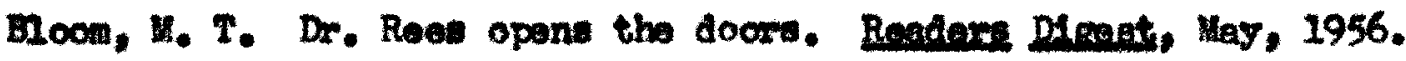

Bower, F. H., Carola-Bunuel, L, Decentralisation Plan. Colorado State Hoopital, Puoblo, Colorado, 1962. (Mineo,)

Brady, J. P., Zellor, T. W., Resnikorf, $M$. Attltidinal faotore InPlnenoing outeome of treatment of howptesleod peyohiatrio patients. I. allin. emp. Prrohonoth., 1959, 20, 326-334.

Bridge日, 1. The Northfleld experiwent. Bull. Henningex culn., 1943, 10, 7-76. 
Br1ggs, D. L. Meaning of 111nese. Hit. Ked., 1957, 120, 198-201.

Brigge, D. L. The hospltal corpsman as a social therepist; an important role in psychlatrlo treatment. Hed. Tech. pul1., 1957, 8, 169-176.

Brigge, D. L. A therapeutic comminity in an oversea Naval hospital. Mil. Hed., 1958, 122, 233-240.

Briggs, D. L. Socili paychiatry in Great Fitsin. Amor. I. Mrreing, 1959, 59, $225-220$.

Brigge, D. L., Stearng, L. Developnents in social peychiatry: observations

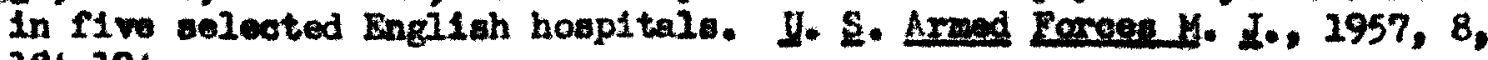
284-194.

Arigg, D. In, \& Wood, Norm R. Advances In training the neuropsyohiatrie technician. I. S. Armed Forces I. I., 1956, 7, 1615-1620.

Buck, Mildred, Lawton, Marcia J. Cbervations of the Clarinda plan in acticn Downey, तil. Anthropology Service, 1961. (Mimeo)

Bul1, Nina A aequence concept of att1tude. I. Peychol., 1946, 22, 165-173.

Campbe11, D. T. The Indireot assesswent of social attitudes. Psychel. Bul., $1950,47,15-38$.

Campbe11, D. T. The Informant in quantitative research. Amer. I. Soctolog. 1955, 4, 339-342.

Campbel1, D. T. Factors relative to the validity of experiments in social settings. Bsychol. Bull., 1957, 54, 297-312.

Campbel1, D. T. Quasi-experimental dealens for use in natural social settings. 1959. (Mimeo)

Campbell, D. T., Stanley, J. C. Experimentel designs for researoh on teaching. In N. L. Cage (Fd.), Handbook of research on teachtng. Chicago: Mollally, 1961. (in press)

Campbell, D. T., Tyler, Bonnie B. The construct vaildtty of work-eroup morale measures. I. appl. Brychol., 1957, 41, 91-92.

Cardno, J. A. The notion of 'attitude', an historical note. Psychol. Rlen." 1, 345-352.

Caudill, W. The psychiatrie hospital as a gmall society. Cambridger Barvard Unfver. Press, 1958.

Caud111, W., Redlich, F. C., Gilmore, H. R., \& Brody, E. B. Soclal structure 
and Interaction processes on psychiatric ward. Amer. I. Orthopsychiat., 1952, 22, 314-334.

Clark, D. H., Kay, R. M. Feform in the mental houpltal: a critical study of a programme. Int. J. soc. Poychiat., 1957, 3, 211-223.

Clausen, J. Soalolog and the field of pental health. Now York: Russell Sage, 1956.

Cohen, R. Sone relationshipe between staff tensicns and the pecyhotherapeutio process. (In press)

Cole, P. More state hoepltal petiente receiving intensive care under decentral1 ation. Pueblo (Colorado) Chloftain, July 11, 1962.

Colo, Myla J., Branch, C. H. Hardin, \& Shaw, Orla M. Mental 1IIness: a survoy assessment of commity rates, attitudes, and adjustments. A. M. A. Arch. Neurol. Paxehtat., 1957, 77, 393-398.

Davie, F. B. Item seleotion techniques. In E. F. Lindquist (Fd.), Educational measurement. Weshington, D. C.: Amer. C. on Eduo., 1951.

Daria, F. B. Item analysis in relation to educational and psychological testing. Pxxchol. Dul1., 1952, 49, 97-119.

De Fleur, $M_{*} \mathrm{~L}_{*}$, \& Catton, $W . \mathrm{R}_{*}, \mathrm{Jr}$. The Iimits of determinacy in attitude moasurement. Soc. Forces, 1957, 35, 295-300.

De Rosis, Helen A., Campbell, R. J. A triel of patient government. Peychiat. cuart. Suppl., 1958, 32, 233-246.

Daljker, H. C. J., Fraisee, P., Melz1, R+, Geron, P., Falliard, J, Les ettitudes. Parie: Presses Universitaires de France, 1961.

Edwarda, A. L. Technloves of attitude soale construation. Nov Yark: Appleton-Century-Crofts, 1957 .

Edwards, A. L., \& Kilpatrick, F. P. A technique for the eculatiotionotiof attitude soales. I. appl. Pexchal., 1948, 32, 374-384.

Edwards, A. I., KIlpetrick, F. P. Scale analysis and the measurement of social attitudes. Paxchometrikg, 1948, 13, 99-114.

Eariel, H. A. A peychoanalytic approsch to group treatrent. Brit. I. ped. Paychol., 1950, 23, 59-74.

Fein, R. Economies of pental 111ness. New York: Basio Books, 1958.

Ferguson, L. $W$. The requirements of an adequate attitude scele. 
Paychol. Bull., 1939, 665-673.

Ferguson, I. W. A study of the Ifkert technique of attitude scale construction. J. soc. Psychol., 1941, 13, 51-57.

Fromm, E. Escape from freodom. Now York: Rinehert, 1941.

From, E. The sane socLety. Now York: Rinehart, 1955.

Galdston, I., Zetterburg, H. (Fds.) Panic and morale. New York: International Universities Press, 1958.

Carrett, H. E. Statigtics in pgyohology and education. New York: Longmans, Green, 1953.

Giedt, F. H. Patterns of attitude similarity among psychiatric hospital staff. Int. I. Boc. Poychiat., 1959, 4, 280-290.

Gillen, J. Soclomoultural therapy-gome cross-eultural ospects. Veterans Administration Program Guide G-3, K-2, Part X, THSS, Psychlatry \& Neurology Service, 1955, June, 17-23.

Gordon, T., \& Carturight, D. S. The effect of psychotherapy upon certein attitudes toward others. In C. R. Rogers \& R. F. Dymond (Eds.), Psvchotherapy and personality change. Chicago: Univ, of Chicago Pross, 1954, Pp. 167-195.

Gough, 11. G. A scolologlcal theory of peychopathy. Amer. J. Eociology, I49, $53,359-366$.

Grace, W. J., \& Graham, D. T. The speciflc relationshlp between attitudes, disease, and motion. Psychogomat. Hed., 1952, 14.

Green, B. F. Attitude meesurement. In G. Lindzey (Bd,), Handbook of social pexchology. Cembridge: Addiscon-Hesloy, 1954,

Croenblatt, $M_{*}$, York, $R_{*} H_{*}$, Brown, Esther L. From custodial to therepeutic patient care in mental hospitale. New York: Rubsell Sage, 1955.

Gregory, C. E. What is morale? Personnel, 1959, 36, 32-41.

Guilford, J. P. Psychometric methods. New York: McGrew-Hill, 1936.

Guilford, J. P. Psychometric methods. New York: McGraw-Hill, 1936.

Guilford, J. P. Fundamentel statistice in peychology and education. New York: MoGraw-H111, 1956.

Guion, R. M. Industrial morale (a symposium): I. The problem of terminology 
Fersonnel Peychol., 1958, 11, 59-64.

Guttman, L. A basis for acaling qualitstive data. Amer. Bociol. Rey., 1944, 9, 139-150.

Guttman, L. The problem of attitude and opinion meaturement. In S. A. Stouffer et al., Meanurement and prediction. Princeton, N. J.: Frinceton Univ. Prest, 1950b. Pp. 60-90.

Ha11, O. M. Attitudee and unemployment. Arch. Peyohol., 1934, No. 165.

Hertman, If. Ego prychology and the problems of adaptation. In D. Rappaport (Ed.), Cgentiotion and patholory of thaught. New York: Columbio univ. Press, 1951. Pp.

Hatoh, Mary E. An inquiry into the attitudes of patients towards their hospltal environment. Unpublished M. S. thesis, Simons College, 1948.

Herzberg, F. I., \& Hamlin, H, $H_{*}$ A motivation-hyglene concept of mental health. Hent. Hys., 1961, 45, 394-401.

Hemer, Kate. An empirical study of three psychophysical methods, I. cen. Peychol., 1930, 4, 191-212.

Hicks, D. C. Croative arts in the psychlatric treatment program, Hed. Tech. BuII., 1957.

Hicks, J. M., \& Spaner, F. E. Attitude change as a function of mental hospitel experience. (Mimeo, to be pubilished.)

Hillzon, J. S., Holfensberger, H. P., Wylle, A. A. Effectis of a complex educetional experience upon attitudes toward mental hospitals. I. educ. Res., (In prese).

Hoover, K. K. An operational analyels of the philosophy, methods, and roanite of the Downey Motivation Unit. Downey, III, : Veterans Adrainistration Hospital, 1961. (Mimeo)

Hovland, C. I. Reconciling conflleting results derived from experimentel and ourvey studies of attitude change. Amer. Paychologlet, 1959, 14, 8-17.

Howard, A. R. Sentence completion as an attitudinal measure. I. edug. Klese, $1956,50,297-305$.

Imre, P. D. Attitudes of volunteers toward mental hospltal compared to petients and personnel. I. clin. Psychol., 1962, 18, 516.

Inre, $P_{*} D_{*}$, \& Wolf, $S$. Attitudes of patlents and personnel towerd mentel 
hosptals. I. alin. Prychol., 1962, 18, 232-234.

Irvine, La V. F., \& Deery, S. J. III, at al. The model ward: a report of progress. Columbia, S. C.: Dept. of Res. \& Development, So. Carolina State Hosp., 1959. (Mimeo)

Johnstone, J. (Jr.) "Attitude" in psychology and peychoscanatic medicine. I. nery. ment. dig., 1953, 4, 287-299.

Jones, M. The therapeutic comennity: a ney treatmont in paychiatry. Nes York: Basic Books, 1953.

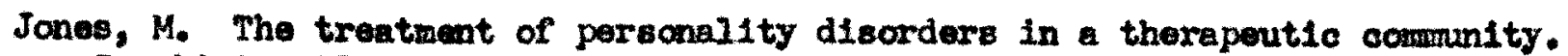
Pexchlat., 1957, 20, 211-220.

Jones, M. Training in social peychiatry at the ward lovel. Amer. I. Psychtat, $1962,118,705-708$.

Jones, Me, Matthewa, R. A. The application of the therapeutic communty principle to a state mental health progran. Exit. I. med. psyohol., $1956,29,57-62$.

Jomes, M., \& Rapoport, R. N. Soclal and adrinistrative psychlatry. Lancet, $1955,269,386-388$.

Jones, Ma, Stallard, F., Hunter, I., Brookes, K. The psychopath and the mental heelth bill. Lancet, 1959, 566-568.

Katzell, R. A. Induetrlal morale (a symposium): III. Measurement of morale. Personnel Psychol., 1958, 11, 71-78.

Kelley, T. L. The selection of upper and lover group for the validation of test 1tems. I. Edue. Peyohol., 30, 17-24.

Kennard, E. A., \& Steiner, G. A. The atudy of wat 1mages. Downoy, III.: Veterane Adminiatration Hospital, Anthropology Service. (Mimeo)

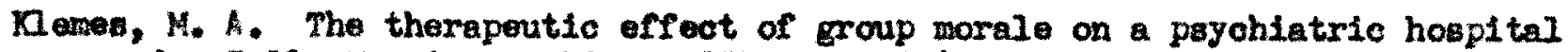
ward. Bull. Menn1nger Glin., 1951, 15, 58-63.

Klopfer, H. G., Wylle, A. A., \& Hilson, J. S. Attitudes toward mentel hospitals. I. clin. Prychol., 1956, 12, 361-365.

Lambert, H. E., L Lowry, F. H. Fffects of the presence and disoussion of others on expreseed att1tudes. Canad. I. Pyychol., 1957, 11, 151-156.

Lana, R. E. Protast-treatnent interaction effecte in attitudinal studies. Dissertation Abstr., 1959, 20, 3\%. 
Lana, R. E. A further investigation of the pretest-treatment interaction offect. J. appl. Frychol., 1959, 43, 421-422.

Learner, D. B. Prychological factors of morale. ISN Sch. Aviat. Hed. rea. 5iep., 1954, Proj. No. M $001058.21-02$.

Laighton, A. H., Clausen, J. A., \& H1lson, R. N. Bxplorations in sacial Dsychiatry. New Xork: Basic Books, 1957.

Levinson, D., G1lbert, D. Ideology, personallty and institutional policy in a mental hospttai. I. abnorm. soc. Paychol., (in press).

Ifbo, L. M. The projective expression of patient therapist attraction. I. clin. Paychol., 1957, 13, 33-36.

Likert, R. A toohnique for the measurement of att1tudes. Arch. PBychol, 1932, No, 140.

Likert, R. S., \& Murphy, G. A simple and rellable mothod of scoring the Thurstone attitude sceles. I. soc. Bsychol., 1934, 5, 228-238.

Main, L. F. The hospltal as a therapeutic institution. pull. Menninger Clin., $1946,10,66-70$.

Mc Gahee, C. L. The ward communty: now route toward long-standing goals. Ment. Hospitals, 1961, 12, 37-39.

Fe Kown, L. N. The measurement of organizational morale. Dissertation Abstr., $1958,19,898-899$.

Me Nenar, Q. Qpinion-attitude methodology. Peychol. Bull., 1946, 43, 289-374. Keerloo, Joost A. M. Mental danger, stress and fear: II. Man and his morale. I. nery. nent. D18., 1957, 125, 357-379.

Menninger, U. C. Faychoanalytic principles applied to the treatment of hospitalized patients. Hul1. Menninger. Clin., 1936, 1, 35-43.

Merton, R. K. Social theory and sociel stmucture. Glencoe, IIl.: Free Press, 1957.

Michaels, J. J. Horale on nouropeychtatrlo gervice in an Arro general hospital. I. nerv. ment. D1s., 1947, 106, 165-175.

Moscovici, S., \& Duraln, Generleve. Cuelques applications de la theorie de I' information a la construction des echelles d' attitudes. Annee psychol.. $1956,56,47-57$.

Muldoon, J. F. FQ: patients' discharge quarters. Ment. HospItals, 1957, 8, $-22-23$. 


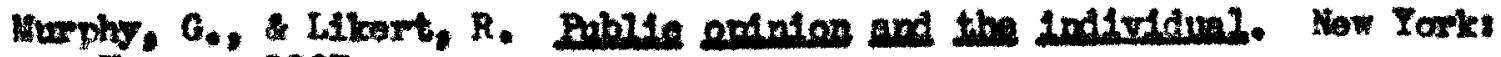
Farpor. 1937.

National Research Counall. Report af a conference on poycholoctoal factors In worale. Division of Authropology and Psycholog, 1940. (U1meo.)

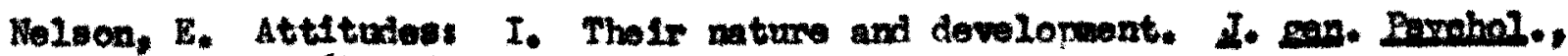
$1939,21,367-399$.

adgers, R. R. Drparlonoes with advanoes in poychlatric patient aere. E. Teah. Bn11., 1956, 7, 244-251.

OLmated, H. S. Tha ma11 Exomn. Now Tork: Rando Howse, 1959.

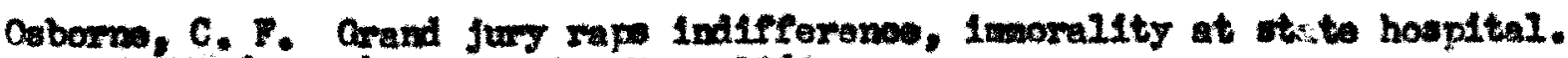
Publo (Colo.) Ahtertiln, Hay, 1962.

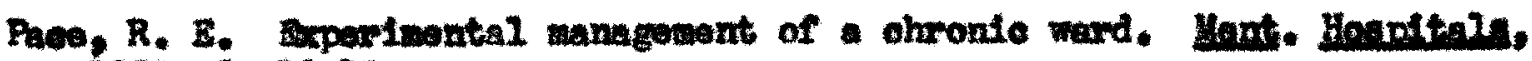
1957. $8,10-12$.

Parken, S. Role theory and the treatwent of the ant1-social eeting-out alsonders. Butt. I. Delsm., 1957, 7, 285-300.

Parker. S. Leaderahip patterns in a poyohiatrie ward. Hom. Ralat., 1958, 11. 287-302.

Parian, 5. Dieorganization on pugohiatrie ward the natural history of a orisis. Prohint., 1959, 22, 65-79.

Poters, F. The yorte pext docs. Iow Yorke Farrar, Strabs, 1949.

Puedy, K. I. Interpersonal relations in a hospltal. I. S. Amed Roreas ned. In, 1956, 7, 1337-1343.

Purdy, K, E, Interporwonal relations in prohlatry oompanan's role in

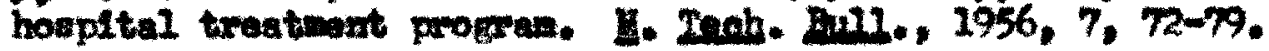

Rapoport, R. N. Osolllations and coototherap. In. Ralat., 1956, 9, 357-374.

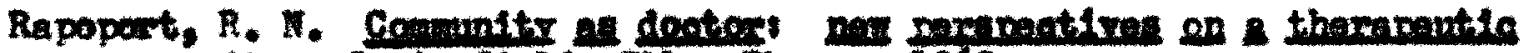
ammontiv. Springfleld, III.: Thomas, 1960.

Rapoport, R. N., Rapoport, Rhome. "Devenowatiention" and authority In a therapeutio oomenuity. Eahat. Set., 1957, 2, 128-133.

Rapoport, Rhon, Roeom, I. An approach to fanfly relationahip and role 
posfarmanoe. Bm. Belat, 1957, 10, 209-221.

Rapoport, R. N. E Skellern, Elloen. Some therapeutio fuotlone of adinistrative diaturbance. Admtn. Set. Gravt, 1957, 2, 82-96.

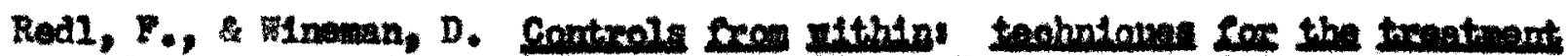

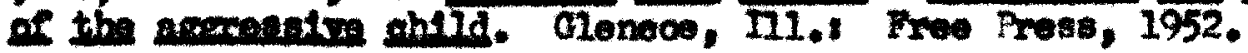

Remers, H. H. In introdution to oninton and attitude mananomant. New Torka Rarpex, 1954.

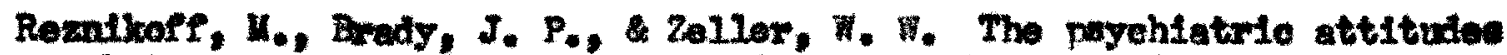
battery a prooedure for abessing attitudes toward poychiatrio troatwent and hospttals. I. stip. Burshal., 1959, 15, 260-266.

Rimold1, H. J. A., Homaeoto, M. The law of oomparative Judguent in swo-

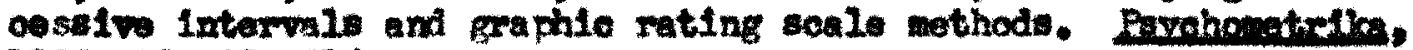
1955. 20, 307-318.

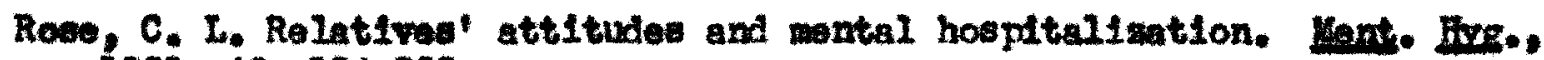
$1959,43,194-203$.

Rosenberg, L. Sootal status and partiolpation anong a group of chronte

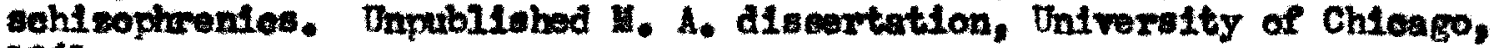
1961.

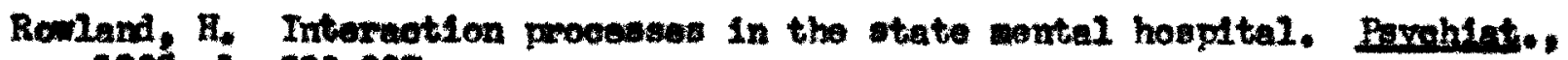
1936, 1, 323-337.

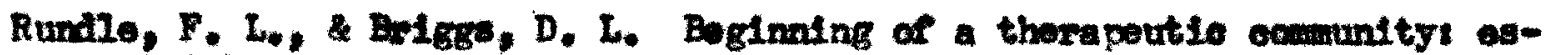

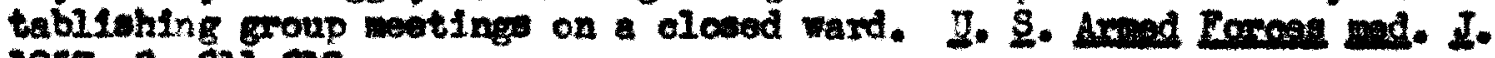
1957, 8, 811-819.

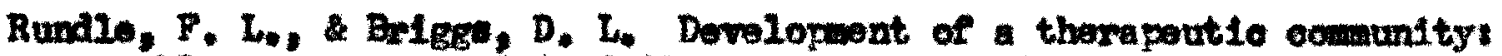
problow enoountered in dally comantty weotings. I. S. Armed Eoren ad. I., 1957, 8, 1339-1349.

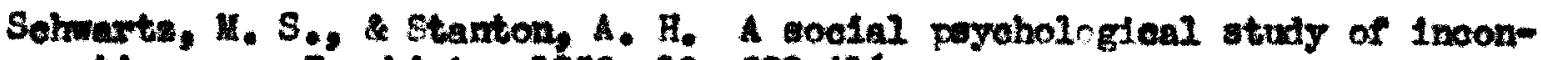
tinenos. Bryhtet., 1950, 13, 399-416.

Seabrook, T. B. Anrlun. How Yorkt Hareourt, 1935.

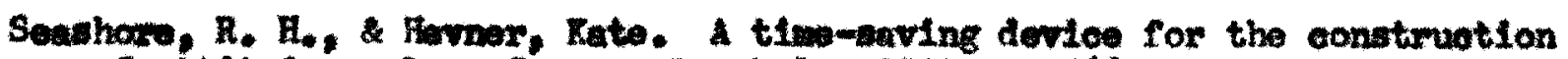
of attitude soales. I. aco. Prechel., 1933, 4, 366-372.

Sewall, O., allin, J, \& LeBax, F. M. Thwough the patient's oyes, Ment. Ave., 1955, 39, 284-292.

Skollers, Blleen. A therapoutio comauntty. Mrraing Itma, 1955, 51, 
$426-428,533-535,593-594,642-643,688-689$.

Sletto, R. F. Construction of personelity scales by the criterion of internal consietency. Minneapolis Sociological Prese, 1937.

Sozmer, $k$. Fatients who grow old in a mental hospital. Cerfatrics, 1959, 14. $581-590$.

Souelem, Mneya. Mental patients' attitudes towkerd mental hospitals. I. clin. Baychol., 1955, 11, 181-185.

Spector, A.J. Forced-choice and projective techniques in attitude noesurement. Personn. Psychal., 1957, 10, 55-59.

Splogel, J. The social roles of doctor and patient in psychoonalyois and psychotherapy. Paychiat., 1954, 17, 369-376.

Stagner, $K$. Industrial morale (a symposium): II. Motivational pects of industrial morele. Personnel Psychol., 1958, 11, 64-70.

Stanton, A. H., \& Schwartz, M. S. The magement of a type of institutional participation in mental iliness. Peychiat., 1949, 12, 13-26.

Stanton, A. H., \& Schwartz, M. S. The mentel hospital. Wow York Bacle Books, 1954 .

Ctephan, F.F. Advances in survey methods and messurement techniques. Publ. Do1n. Qusat., 1957, 21, 79-90.

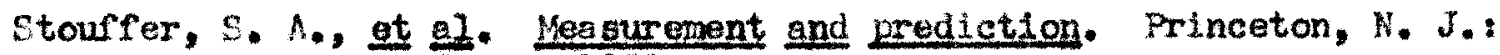
Frinceton Univ. Fress, 1950.

Stephen, F. F. Advances in survey methods and messurement teohniques. Publ. opin. wart., 1957, 21, 79-90.

Sullivan, H. S. Modified pgychoonalytic trentment of sehizophreniz. Amer. I. Psychiat., 1931, 519-540.

Sullivan, H. s. Sociompyohintrio Pesearch: its implications for the schlzophronir jroblem and for mental hyglene. Anar. J. Peychiet., 10, 1931, 977-991.

Sullivan, H. S. Whe interpersonal theory of pevchiatry. New York: Worton, 1953.

Tate, M. U. Statistiog in education. New York: Macmillan, 1955.

Taylor, S. The prychopath in our midst: a hanieh olution. Lancet, 1949, 
$256,32-36$

Thurstone, L. 1. A Iay of comparritive judgment. Bgychoi. Rev., 1927, 34, $273-286$.

Thurstone, L. L. The method of peired comparisons for socikl vaiues. I. abnorm. soc. Peychol., 1927, 21, 384-400.

Thurstone, L. L. Comment. Amer. I. Sociol., 1946, 52, 39-50.

Thuratone, L. L., \& Chave, E. J. The messurement of attitude. Chicago: Univ. Chicago Prese, 1929.

Toch, H. H. The perception of high and low mora 1e. Pergonnel Perchol., 1957, $10,407-420$.

Torgereon, .. S. Theory and mothods of gceling. Hew York: Wiley, 1958.

Upehaw, H. s. Om attitude as an snchor in equal-appearing interveli. I. abn. soc. Bychol., 1962, 64, 85-96.

Vaughn, R. M. Some lint tations of the psychotherapeutic model in the hosp1tal. Ment. Mospltale, 1962.

Vitale, J. H. The theropeutic comanity: a review article. St. Louls Sccial cience Institute truining program for research in comunity mental health, 1\%1. (Mimeo)

Vang, K. A. Suggested criteris for writing attitude statemonts. I. goc. Psxchol, 1932, 3, 367-373.

Ward, Mry J. The snake pit. Now York: landom, 1946.

Hebb, 4. 4 . longtudinal socio-psychologic study of a randomly selected group of institutionalized veterans. I. Amar. Ceriat., Soe., 1959, $7,730-740$.

Webb, N. J. Mersurement of attitude and information changes in mentaI hea Ith concepts among seminarians. Unpublished doctoral disertation, Loyole lintversity, 1959.

Webb, N. J., \& Kobler, $\mathrm{N}$. I. Clinical-emplrical techniques for assessing the attitudes of religlous townd peychlatry. J. 800. Psychol.* 1\%2.

Merry, R. J. Industrial morale (a syraposium): IV. Factior analysis of norale data reliability and validity. Personnel Paychol., 1958, 11, $78-89$.

Willinghan, $W$. Whe sentence-completion test as a meesure of norale 
91

USN Sch. Ariat. Med. res, Rep., 1958, Proj, No. M 1601 11, Sub. 4, No. $4111,6,4-9$.

Willis, S. E. Treatment milieu; its importance in prognosis of schizophrenias. U. S. Armed Forces M. J., 1954, 5, 704-712.

Wilmer, H. A. A paychiatrio aervice as a theraneutie comulty. U. S. Armed Forces M. I., 1956, 7, 640-654.

Wilmer, H. A. Treatnent of mental illnes: the use and misuse of sedation and the seciusion rook. Cal1f. Med., 1957, 86, 93-98.

Wilmer, H. A. Bractical social psychiatry: a thorapeutic compounity. Springfield: Cherles C. Thowes, 1958.

Wilmer, H. A. Toward a definition of the therapeutio commity. Amer. I. Paychiat., 1957-1958, 114, 824-834.

Wing, J. K. Institutionalion in nental hospitalo. prit. J. Eoc. clin. Psychol., 1962, 1, 38-51.

Wolfensberger, W. P. Attitudes of elcohallos toward mental hospitals. cuart. I. Stud. Ale., 1958, 19, 447-451. 


\section{Foornores}

1. Chestnut Lodge, Maryland.

2. Four were PhD. level poychologists on the staff of the Downey $V$. A. Ilospital. Four were V. A. trainees from two universities in the Chicago area. All of the fualges had clinical experlence on the ward level.

3. This description io besed on an unpublished research plen, mimeographed by the Psychology Service of the Downey V. A. Hospital and entitied "An operational andysis of the phllosophy, nethods, and reeults of the Downey Motivation Unit" (Hoover, 1961). 


\section{APPENDIX I}

INC OMPLETE SEMTENCES FORM

Directions: This 18 one part of a hospital research project. For this we noed to know what people think about their different werds. We would greatly appreciate your cooperation.

The beginning words of some sentences are printed below. Please complete them in your own vords. Feel free to say what you think. You do not need to al gn your namo.

1. Being on this ward moke me feel...

2. The best thing about this ward 18...

3. The ataff members on this ward should ...

4. Those petients who don"t like being on this ward...

5. The worst thing about this werd...

6. Those petients who $11 \mathrm{ke}$ being on this ward...

7. The therapy program on this ward is...

8. The aides (nuraing essiotants) on this ward...

9. If I were in charge of this ward, I would...

10. The best thing about the staff members on this ward is...

\section{Additional Coments}


APPENDIX II

SPETSTICAL DATA FOR SCAJING

Item

Prequency

Proportions

Cumulative Proportions
(1)
(2)
(3) (4) (5)
(1) (2) (3) (4) (5)
1122
34

1

$2-53117$ 14 12

$3446117 \quad 24 \quad 11$

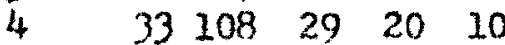

$\begin{array}{llllll}5- & 7 & 21 & 33 & 107 & 32\end{array}$

$\begin{array}{llllll}6 & 47 & 114 & 16 & 20 & 3\end{array}$

7. $\quad \begin{array}{lllll}6 & 19 & 51 & 98 & 26\end{array}$

$\begin{array}{lllll}8 & 44 & 126 & 18 & 9\end{array}$

$\begin{array}{lllll}9- & 12 & 22 & 20 & 110\end{array}$

10.

11

$12-$

$13-$

14

15-

16.

17

18.

19

20

21 -

22

23

$24-$

25

26

$27-$

28
$10 \quad 26$

47106

514

$15 \quad 29$

$49 \quad 115$

820

$10 \quad 23$

$46 \quad 99$

1245

$40 \quad 94$

55107

79

45105

45123

$\begin{array}{ll}5 & 18\end{array}$

4197

936

2120

4? 112
4790

$25 \quad 16$

45105

$36 \quad 96$

$16 \quad 18$

34106

34101

$25 \quad 24$

$33 \quad 87$

312

$15 \quad 15$

$30 \quad 111$

$25 \quad 19$

1612

34104

$23 \quad 22$

$45 \quad 88$

32110

22 19
3

36

27

6

31

24

2

32

32

6

23

10

8

43

6

4

39

12

2 ?

27

5
$.26 .59 .07 \quad .06 \quad .02$

.04 .04 .16 .54 .22

.23 .58 .12 .06 .01

.16 .54 .15 .10 .05

.04 .10 .16 .54 .16

.24 .57 .08 .10 .01

.03 .09 .26 .49 .13

.32 .63 .09 .04 .02

.06 .11 .10 .55 .18

$.05 .13 .24 . .45 .13$

$.24 .53 .12 .08 \quad .03$

.02 .07 .23 .52 .16

.08 .14 .18 .48 .12

.24 .58 .08 .09 .01

.04 .10 .17 .53 .16

.05 .12 .17 .50 .16

.23 .50 .12 .12 .03

.06 .22 .26 .44 .22

.20 .47 .15 .12 .05

.27 .54 .07 .08 .04

.04 .04 .15 .56 .21

.22 .52 .13 .10 .03

.22 .62 .08 .06 .02

.02 .09 .17 .52 .20

.21 .48 .14 .11 .06

$.05 .18 .22 .44 . .11$

$.05 .10 .16 \cdot .55 .14$

.21 .56 .11 .10 .02

$\begin{array}{lllll}.020 & .080 & .150 & .735 & 1.000 \\ .045 & .090 & .250 & .785 & 1.000 \\ .010 & .065 & .185 & .770 & 1.000 \\ .050 & .150 & .295 & .835 & 1.000 \\ .035 & .140 & .305 & .840 & 1.000 \\ .015 & .115 & .195 & .765 & 1.000 \\ .030 & .125 & .380 & .870 & 1.000 \\ .015 & .060 & .150 & .780 & 1.000 \\ .060 & .170 & .270 & .820 & 1.000 \\ .050 & .120 & .415 & .865 & 1.000 \\ .030 & .110 & .235 & .765 & 1.000 \\ .025 & .095 & .320 & .845 & 1.000 \\ .075 & .220 & .400 & .880 & 1.000 \\ .010 & .100 & .180 & .755 & 1.000 \\ .040 & .140 & .310 & .840 & 1.000 \\ .050 & .165 & .335 & .840 & 1.000 \\ .030 & .150 & .275 & .770 & 1.000 \\ .060 & .285 & .450 & .885 & 1.000 \\ .050 & .175 & .330 & .800 & 1.000 \\ .040 & .115 & .190 & .725 & 1.000 \\ .035 & .080 & .230 & .785 & 1.000 \\ .030 & .125 & .250 & .775 & 1.000 \\ .020 & .080 & .160 & .775 & 1.000 \\ .025 & .115 & .285 & .805 & 1.000 \\ .050 & .170 & .310 & .795 & 1.000 \\ .045 & . .225 & .450 & .890 & 1.000 \\ .055 & .155 & .315 & .865 & 1.000 \\ .025 & .120 & .230 & .790 & 1.000\end{array}$

- indicates an unfavorably worded statement. 
APENDIX III

CMTISICAL UNA FO SCALIHO

\section{Normal Deviatos}

\section{Lpper Lintto}

$\begin{array}{llllllllll}\text { Itam } & 0 & 1 & 2 & 3 & 4 & 0 & 1 & 2 & 3\end{array}$

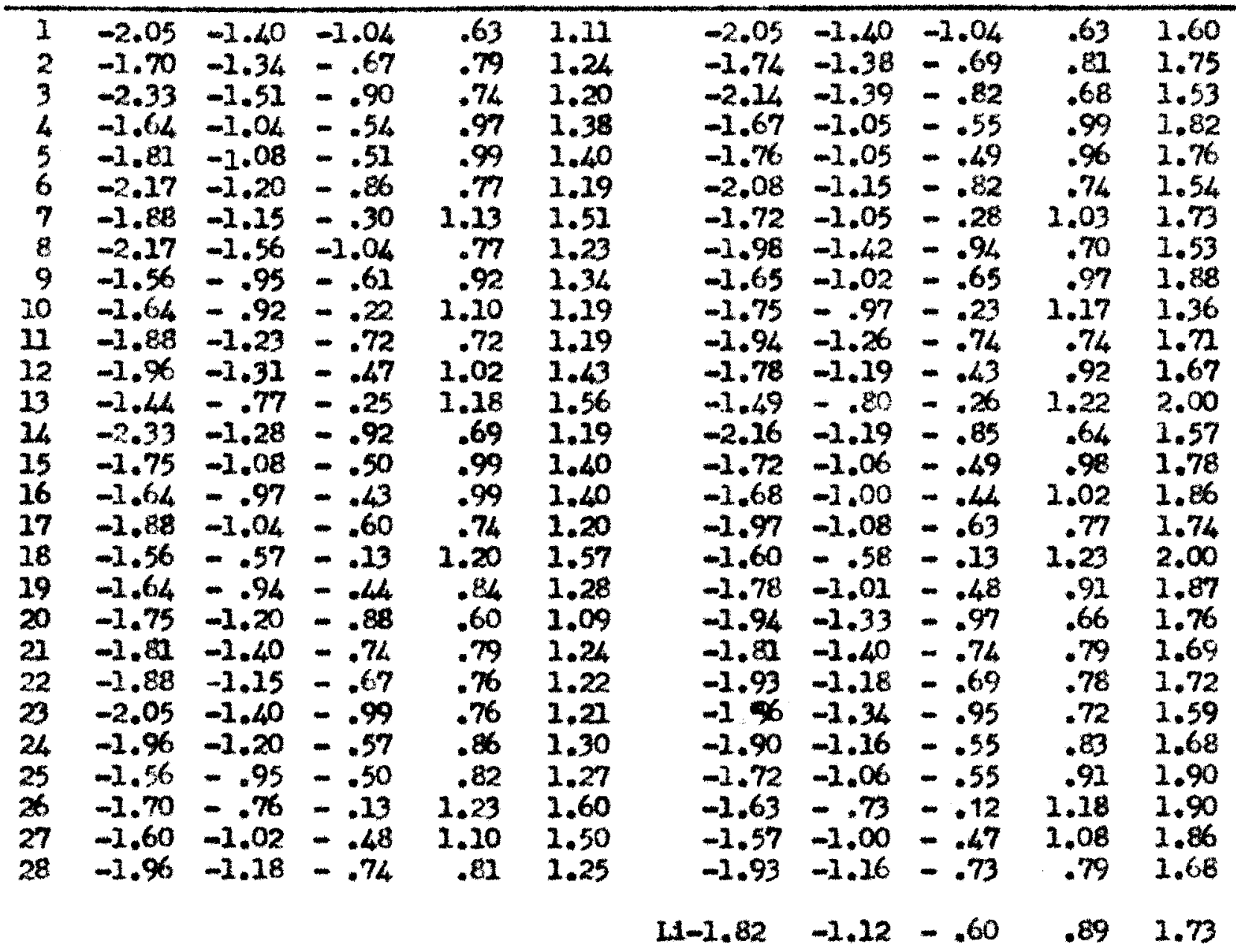


APPUIDIX TV

WARD RAT TO SCALE

Dtrectiong: This rating soale is part of a hospltal research projeot. The atatements printed below were wade by patients in varlous wards of several hospitale. Wo would like to know if you feel the same way about the ward you are on in this hospltal. Please read oach otatement carefully. Then thow how moh you agree or diagree with it by underilning one of the flve oholees under eaoh statement.

Showing how you honestly feel will help ws deternine the value of present treatment mothoda. So that no one will know what you think, please do not aign your nawe. Iow help 111 be greatly appreclated.

1. Host of the perconnel assigmed to thi ward axe understanding of the pat1ontim.
(1) Strongly agrea
(2)Agreo
(3) Undeatded
(4)Disagree
(5) Strongly disagree

2. Time pasees alowly on this ward.
(1) Strongly agree
(2) Agree
(3) Undeoided
(4)Disagrae
(5) Strongly alsagree

3. The murees who work an this ward do thair best to holp the patients. (1) Strongly agroe (2) Agree (3) Indeetded (4)Disagroe (5) Strongly diagree

4. I 11ke to stay away frow this ward as weh as posstble.
(1) Strongly agres
(2) Agree
(3) Undealded (4)Diagaree
(5)Strongly disagree

5. The aides on this ward do holpful things oven when they don't have to. (1) Strongly agre (2) Agree (3) Indeolded (4) Diagreo (5)Strongly disagreo

6. There are equal opportunitien for everybody on this ward.
(1) Strongly agree
(2) Agres
(3) Undeoided (4)Disagree
(5) Strongly disagree

7. The aldes on this ward play an importeut part in helping the patients. (1) Strongly agree (2) Agree (3) Undeolded (4)Dieagres (5) Strongly disagree

8. Staff nembers bulld up falue hopes in the minis of the patients on this ward.
(1) Strongly agree
(2) Agres
(3) thieelded
(4)Disagrea
(5) Strongly dieagree

9. On this ward, "getting better" meane keeplng gour thoughte to yourself and minding your oun businese.

(1)Strongly asree (2) Astree (3) Undeolded (4)Disagree (5) Strongly dieagree 
10. The utaff mewbers on this ward take ti to Ilaten to the patients.
(1) Strongly agree
(2) Agree
(3) Ondeelded (4)Disagree
(5) Strongly dieseree

11. There are too many "ptuffed-shirts" on the ward staff.
(1) Strongly agree
(2) Agreo
(3) Undeclded
(4)Disagree
(5) Strongly disagreo

12. The aldes on this ward are afraid of the patients.
(1) Strongly agree
(2) Agree
(3) Undecided
(4)Disagree
(5) Strongly disagrea

13. On this ward, you get ooperation from the otaff members.
(1) Strongly agree
(2) Agree
(3) Undeolded
(4)Disagree
(5) Strongly dieagree

14. There are too eny fighte on this ward.
(1) Strongly agree
(2) Agree
(3) Indeolded
(4)D1aagreo
(5) Strongly disagree

15. There' too wuoh wattint on this ward.
(1) Strongly agroe
(2) Agree
(3) Indeoided
(4)Disagree
(5) Strongly disagree

16. The etafe members of this ward spend too much tiwe on coffec breaks.
(1) Strongly agree
(2) Agroe
(3) Undeotded
(4)Disagree
(5)Strongly disagreo

17. The ataff momber on this ward nlay favorttos.
(1) Strongly agree
(2)Agres
(3) Undeelded
(4)Disagres
(5) Strongly disagreo

18. The medieal doctor(s) who serves this ward is doing all he oen to help the patients.
(1) Strongly agree
(2) Agree
(3) Underelded
(4)Diangroe
(5)Strongly dieagree

19. The therapy program on this ward is very helprul to the patients.
(I) Strongly agree
(2)Agree
(3) Undeotided (4)Disagree
(5) Strongly disagree

20. The pass procedure on this ward is fair.
(1) Strongly agree
(2) Agroe
(3) Undeolded (4)Disagees
(5) Strongly d1sagree

21. Iou don't see many smiles on this ward.
(I) Strongly azoso
(2) 1 z०a
(3) Indeatdas
(4)Diargea
(5)Strongly disagree

22. I don't plnce much trust in what they pronise the patiente on this vard. (1) Strongly agree (2) Agree (3) Undeolded (4)Dlageree (5) Strongly dieagree

23. Hardly anyons on this ward understands me.
(1) Strongly agree
(2) A
(3) Indecided (4)Diangreo
(5)Strongly disagree

24. The patients on this ward have coneldence in the staff.
(1) Strongly agree
(2) Agree
(3) Undecided (4)Diangree
(5) Strongly disagreo

25. There is a splrit of cooperation among the staff on thia ward.
(1) Strongly agrea
(2) Agree
(3) Undeoided
(4) Diagree
(5) Strongly disagroo

26. The aldes on this ward do a fine job.

(1) Strongly agree (2)Agree (3) Undeolded (4)Dieagree (5)Strongly disagreo 
27. On th1e ward they make you take tranquilizere whether you need them or not (1) Strongly agree (2) Agree (3) Undeotded (4)Diagree (5) Strongly diagareo

28. The dootory who eerve this ward avold their patients.
(1) Strongly agroo
(2) Agree
(3) Undootded
(4)Diagree
(5) Strongly dieagree

29. It's hard to ind somene to talk with on this rard.
(1) Strongly agree
(2)Agroo
(3) Ondeolded (4)Dieagree
(5) Strongly diwagxee

30. Some of the aldes on this ward should be fired.
(1) Strongly agree
(2) Agree
(3) Undeclded (4)Diangree
(5) Strongly alsagree

31. The therspy prograt on this mard is excellent.
(1) Strongly agree
(2) Agrea
(3) Undeotded (4)Disagree
(5) Strongly Alagaree

32. I would transfer to another ward, if possible.
(1) Strongly agroe
(2) Anree
(3) Indec1ded
(4) Dieagroe
(5) Strongly alsagree

33. The nurses who servo this naxd are too bospy.

(1) Strongly agree (2) Agres (3) Undecided (4) Disagreo (5) Strongly alsagree

34. The petiente on this ward are nogleoted by the ataff.

(1) Strongly agree (2)Agree (3) Undeolded (4)Disagree (5) Strongly disagreo

35. The otaff membere on this werd know what they're doinge
(1) Strongly agres
(2) Agree
(3) Undeolded (4)DLaagree
(5) Strongly alsagree

36. The otaff membera on this ward keep the patients up-to-date on their ocndition.
(1) Strongly agree
(2)Agreo
(3) Undeolded (4)Disagree
(5) Strongly disagree

37. The patients on this ward don't get a ohanoe to manage their own affatra.
(1) Strongly agras
(2)Agreo
(3) Indeolded (4)Dingreo
(5) Strongly disagreo

38. Tha dootors who serve this ward spend enough tine with the natients.
(1) Strongly agree
(2)Agree
(3) Undectded (4)Diagree
(5) Strongly disagreo

39. Several members of the ward otaft coen unmure of thesselves.
(1) Strongly apsee
(2) Agree
(3) Trulecided (4)Diengree
(5) Strongly disagree

40. They'vo done overything they onuld to make thle ward a pleasant place. (1) Strongly agree (2) Agree (3) Undeolded (4)DLagare (5) Strongly diagree

41. The people who run this ward Iike to "pass the buok".
(1) Strongly agrae
(2) $1 \mathrm{~g}=0 \mathrm{a}$
(3) Indeotded
(4) Dieagree
(5) Strongly alsagree

12. The ataff on this ward show 11ttle personal interest in me.

(1) Strongly agree (2) Agree (3) Undeolded (4) Diwagree (5) Strongly diagree

43. There's an optinietio spirit on this ward.
(1) Strongly agroe
(2) Agree
(3) Undeolded (4)Disagreo
(5) Strongly d1aggee

98 
44. I have very fow oomplaints to make about this ward.

(1) Strorgig agres (2)Agree (3) Undeolded (4)DLaggres (5)Strongly dieagreo

45. I an afreld of what might happen to if I ald what I think about this vard.
(1) Strongle apree
(2) Agree
(?) Indecided
(4)Disagree
(5) Strongly disagreo

46. It was a resi break boing as signed to this vard.
(1) Strongly agreo
(2) Agree
(3) Undecided (4) Diagroe
(5) Strongly disagree

47. The aldes on this wart are too bossy.
(1) Strongly agree
(2) Agreo
(3) Undectded
(4) Disagree
(5) Strongly disagreo

48. The nurees on this ward are inolined to forgat what a patient asks them to do.
(1) Strongly agree
(2) $\operatorname{tg}$ ree
(3) Undeolded
(4)Dimgree
(5) Strongly diangree

19. There Ion't enough privacy for the patients on this ward.
(1) Strongly agreo
(2)Agree
(3) Undeolded
(4)Disagra
(5)Strongly disagree

50. Hoot of the nurses who eerve this ward are excellent,
(1) Strongly agree
(2) Agree
(3) Undecided
(4) DLagres
(5) Strongly disagrea

51. I fust don't Iive the way they do things on this ward.
(1) Strongly agree
(2) Agreo
(3) Undeolded
(4) Disagree
(5) Strongly alsagree

52. The petients on this waxd get chanees to make suggestions.
(1) Strongly apres
(2) Agree
(3) Undesided
(4)Dleagrae
(5) Strongly alsagree

53. Thar give you enough freedom on this ward.
(1) Strongly agree
(2) 1 geres
(3) Undoolded
(4)Diangree
(5) Strongly disagrae

54. There's a lot of talk and I1ttle action on the part of this wand's otafe. (1) Strongly agree (2) Agree (3) Undeolded (4) Disagree (5) Strongly disagreo

55. Some of the etafe members on this ward could atand some payohiatrio treatment.
(1) Strongly agres
(2) Agree
(3) Undeotded (4)Disagree
(5) Strongly diangree

56. Host of the stafe members on this ward are doing as moch as they oan to help the patiente.
(1) Strongiy agreo
(2) Agreo
(3) Undeolded
(4)Diaagree
(5) Strongly dianger

57. The aldes on this ward are understanding of the patients.
(1) Strongly agree
(2) Agroe
(3) Undeolded (4)D1 aagree
(5) Strongly disagree

58. I an happy on this ward.
(1) Strongly anree
(2) Agree
(3) Undeolded
(4) DLagree
(5) Strongly dieagres

59. Those patients who are able to take on responsibilitles can do so on thia vand.
(1) Strongly agree
(2) Agree
(3) Undeolded (4) D1eagreo
(5) Strongly disagreo 
60. The etaff metabers on this ward take tine to telk with patients.

(1) Strongly agreo (2)Agree (3) Undeolded (4)Disagree (5) Strongly dieagree

61. Being on thlo waxd helps me make ow deotoions.

(1) Strongly agree (2) Agree (3) Undeoided (4) Disagree (5)Strongly alaagreo

62. Thare are too many rales and requlations on this ward.

(1) Strongly agree (2) Agree (3) Indeolded (4)olagroe (5)Strongly disagrea

63. This ward is corrosaing.

(1)Strongly agree (2)Agree (3) Undectded (4)Dlesgrae (5)Strongly alsagree

64. They treat you like a huan being on this fard.
(1) Strongly agreo
(2) Agreo
(3) Undeolded
(4)Diangree
(5) Strongiy disagree

65. On this ward you can be of real help to othera less fowtunate than youmsal (1) Strongly agree (2) Agree (3) Undeolded (4)Disagres $(5)$ Strongly al aagree

66. The dootors who serve this ward think they "know it ali".

(1) Strongly agree (2) Agres (3) Undectied (4)Disagrea (5) Strongly disagree

67. The ward doctor is a nice guy.

(1) Strongly agree (2) Agree (3) Indeclded (4) Disagree (5)strongly disagreo

68. On this ward, they treat the patients like human beings.

(1) Strongly agres (2) Agreo (3) Indeolded (4)Disagree (5) Strongly disegree

69. On this wert, the nurses are patient and understanding;

(1) Strongly agre (2) Agree (3) Indeolded (4)D1sagres (5) Strongly disagreo

70. They treat you 11ke an Individual on this ward.

(1) Strongly agreo (2)Agreo (3) Unclectded (4)Disagree (5) Strongly diacaree

7. It's upaetting to be on this ward.

(1) Strongly agree (2) Agroe (3) Undeolded (4)Disagroe (5) Strongty disagroe

72. They don't give the patients enough reading waterlel on this ward.
(1) Strongly agree
(2) Agroc
(3) Undeclded (4) Disagreo
(5) Strongly aliagreo

73. The staff mambere of this ward seen to know what they're doing.
(1) Strongly agree
(2) Agree
(3) Indeotded
(4) Diangee
(5) Strongly disagree

74. The aides on this ward are interested in thetr work.
(1) Strongly agree
(2) Agroo
(3) Undectded
(4)Disagree
(5) Strongly alsagree

79. On thte ward, they're too otrlet about patients 1 ying on thatr beds during the day.

(1) strongty ares

(2) Astoe

(3) Indecided

(4)Diangres

(5)Strongly deseree

76. Paing on this ward helps ne feol better about the future. (1) Strongly (2) Agree (3) Undacided (4)Disagree (5) Strongly Alsegree 
77. Being on this ward has helped wo.

(1) Strongly agree (2)Agree (3) Undeoided (4)Disagree (5)Strongly diagreo

78. Belng on this ward does more harm than good to a patient.

(1) Strongly sgree (2) Agree (3) Undeolded (4)Diragree (5) Strongly dieagree

7. There's too mush nolse on this ward.

(1) Strongly agree (2)Agree (3) Undeoided (4)Diagreo (5)Strongly diagreo

80. The aldes on this ward are lazy.

(1) Strongly agroe (2) Agree (3) Undecided (4)Disagreo (5)Strongly disagree

81. There's not enough to keep you busy on this ward.

(1) Strongly agree (2) Agree (3) Undeolded (4)Disagree (5)Strongly dieagree

82. They do tho1r best to keop this ward noat and olean.

(1) Strongly agreo (2) Agree (3) Undeelded (4)Diaagree (5) Strongly disagreo

101 


\section{APRENDIX V: \\ PATIENTS OPINION POLL}

Dixeationat Th1s poll is part of a hospital research profeot. The statements on the following pages were made by pationts in various wards of several hospitals. would 11ke to knom how yon feel about these conditions on your ward. Fosd each statement earefully. Then shom how muoh you agree or disagreo with it by underlinine ane of the choices under each statement.

Showing how you honestily feel will help to determine the value of present treatment methods. You do not noed to stan your name. Your help will be ereatly appreciated.

1. The patients on this ward get ohances to make suggestions.
(1) Strongly agree
(2) Agreo
(3) Undeolded
(4)Disagreo
(5) Strongly disagree

2. Bolng on this ward does more harm than good to a patient. (1) Strongly agreo (2) Agree (3) Undocidod (4)Disagree (5) Strongly diagreo

3. There 18 a spirit of cooperation among the staff on this ward.
(1) Strongly agree
(2) Agroo
(3) Undecided
(4) Disagroo
(5) Strongly disagree

4. Being on this ward helpe make my own deafsions.
(1) Strongly agree
(2) $\operatorname{Ag} x$
(3) Uniecided
(4)Disagroe
(5)Strongly disagroe

5. The dootors who serve this ward think they "know it all".
(1) Strongly agree
(2) Agree
(3) Undecided
(4) Disagree
(5) Strongly dieagreo

6. They've done overything they oould to make this ward a pleasant nlace.
(1) Strongly agree
(2) Agree
(3) Undeolded
(4)Disagreo
(5) Strongly disagreo

7. The ataff members on this ward play favorites.

(1) Strongly apro (2) Agree (3) Hndeatdad (4)Disagreo (5) Strongly disagree

8. On this ward, they treat the patients like human beings.

(1) Strongly agree (2) Agree (3) Undeolded (4)Disagree (5) Strongly disagres

9. It's hard to find someone to ta?k with on this ward.

(1) Strongly agree (2)Apree (3) Undecidod (4)Disagree (5) Strongly disagree

10. I don't place much trust in phat they promiso the patiants on this ward. (1) Strongly agreo (2) Agree (3) Indecided (4)Disagroe (5) Strongly disagree 
11. Boing on this ward has holped we.
(1) Strongly agree
(2) Agreo
(3) Undeo1ded
(4)Dlsagreo
(5) Strongly disagree

12. I just don't 11ke the way they do things on this ward.

(1) Strongly agreo (2)Agree (3) Undeolded (4)Disagree (5) Strongly disagreo

13. The patients on this waxd don't get a chanoe to manage their own affalrs. (1)Strongly agree (2) Agree (3) Undecided (4)Dlaggree (5)Strongly diagree

14. The staff movors on this ward take time to Iisten to the pationts.

(1)Strongly agree (2)Agree (3) Undeoided (4)Diagree (5) Strongly dibagree

15. There are too many rulas ant regulations on this ward.

(1) Strongly agroe (?)Agrea (3) Indecided (4)Disagres (5) Strongly disagree

16. This ward is depressing.

(1)Strongly agreo (2)Agreo (3) Indeoided (4)Disagroe (5)Strongly dieagree

17. The aldes on this ward do helphul things evon when thay lon't have to. (1) Strongly agres (2)Agree (3) Undectded (4)Disagree (5) Strongly disagreo

18. Tou don't soe many ontloe on this ward.
(1) Strongly agreo
(2)Agree
(3) Undeolded
(4)Disagree
(5) Strongly afsagree

19. Bolas on this wand helps mo feel botter about the future.

(1) Strongly agroe (2) Agrea (3) Undeolded (4)Disagree (5) Strongly disagree

20. They give you enough freciom on this ward.
(1) Strongly agres
(2) Agree
(3) Undeoided (4)Diengreo
(5)Strongly diagree

21. The petiento on tint ward are neglected by the stars.
(1) Strongly argeo
(2) Agres
(3) tindectad
(4)Diasgree
(5) Strongly disagree

22. There are equal opportunftes for averybody on this ward.
(I) Strongly agree
(2) Agree
(3) Undeolded
(4)Disagree
(5) Strongly disagree

23. The staff members of this ward seam to know what thoy're doing.
(1) Strongly agree
(2) Agres
(3) Undeolded
(4)Diaagree
(5) Strongly disagree

24. Some of the aldes on this ward should be fired.
(1) Strongly agree
(2)Agree
(3) Undeolded
(4)Dimagnee
(5) Strongly assagree

25. I an happy on this ward.
(1) Strongly agres (2) Agros
(3) Indecited
(4)Dieagree
(5) Strongly alsagree

26. There's too muoh waltine on this ward.
(1) Strongly agreo
(2) Agree
(3) Undecided
(4) Disagree
(5) Strongly disagree

27. The nurees on this ward are inelined to forget what a patient asks then to to.
(1) Strongly agree
(2) Agree
(3) Undeatded
(4)Diagree
(5) Strongly dieagree 
28. I have rery few conplaints to make about this ward. (1) Strongly agree (2)Agree (3) Undeolded (4)Disagree (5)Strongly disagreo 
APERTIL SHEET

The dissertation subutted by w1ziem Grogory nett has boon reat and a prover? by flve nembers of the Depertnent of Psyohologe.

The flus noptes how boon oxautrot by the diroctor of the diasertation and the stgrature which aprens below vertefen the fret that any necersar, ahruges have boen

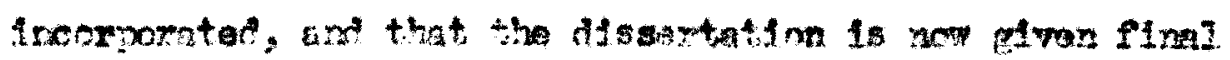

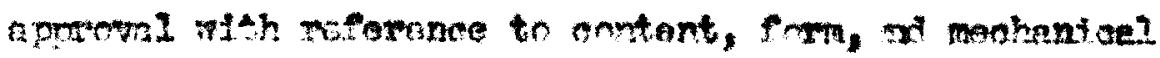
actarey.

The diswartation is tharefm aocepted in partial werilment of the reguirerantis for the Dogres of Doctor o. milnashy.
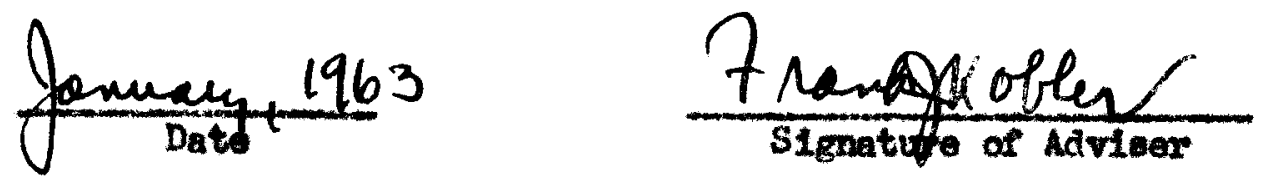